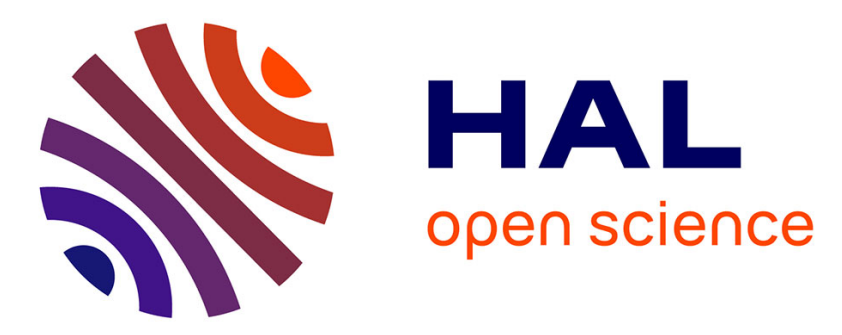

\title{
Synthesis, structure and magnetic behavior of iron arsenites with hierarchical magnetic units
}

Bastien Leclercq, Houria Kabbour, Angel M Arevalo-Lopez, Sylvie

Daviero-Minaud, Claire Minaud, Rénald David, Olivier Mentré

\section{To cite this version:}

Bastien Leclercq, Houria Kabbour, Angel M Arevalo-Lopez, Sylvie Daviero-Minaud, Claire Minaud, et al.. Synthesis, structure and magnetic behavior of iron arsenites with hierarchical magnetic units. Inorganic Chemistry Frontiers, 2020, 7 (20), pp.3987-3999. 10.1039/D0QI00887G . hal-03291932

\section{HAL Id: hal-03291932 \\ https://hal.science/hal-03291932}

Submitted on 20 Jul 2021

HAL is a multi-disciplinary open access archive for the deposit and dissemination of scientific research documents, whether they are published or not. The documents may come from teaching and research institutions in France or abroad, or from public or private research centers.
L'archive ouverte pluridisciplinaire HAL, est destinée au dépôt et à la diffusion de documents scientifiques de niveau recherche, publiés ou non, émanant des établissements d'enseignement et de recherche français ou étrangers, des laboratoires publics ou privés. 


\title{
Synthesis, Structure and Magnetic behavior of iron arsenites with hierarchical magnetic units
}

Leclercq Bastien ${ }^{\alpha}$, Houria Kabbour ${ }^{\alpha}$, Angel M. Arevalo-Lopez ${ }^{\alpha}$, Sylvie Daviero-Minaud ${ }^{\alpha}$, Claire Minaud $^{\beta}$, Rénald David ${ }^{\alpha}$ and Olivier Mentré ${ }^{\alpha, *}$

a UCCS, UMR-CNRS 8181, Bâtiment C7 Ecole Centrale, Université Lille, Avenue Mendeleiev, 59655 Villeneuve d'Ascq, France.

${ }^{\beta}$ Institut Chevreul, Bâtiment C4, Université Lille, Cité scientifique, 59655 Villeneuve d'Ascq, France.

* : corresponding author

\begin{abstract}
The standard redox potentials of the $\mathrm{Fe}^{3+} / \mathrm{Fe}^{2+}(+0.77 \mathrm{~V})$ and $\mathrm{H}_{3} \mathrm{AsO}_{4} / \mathrm{H}_{3} \mathrm{AsO}_{3}(+0.56 \mathrm{~V})$ stabilize the easy crystallization of ferric arsenates. However, activating solvothermal reactions with a reducing agent such as hydrazine or ethanol may destabilize the solid compounds towards ferric, ferrous or mixed $\mathrm{Fe}^{2+/ 3+}$ arsenites. Few of them have been reported and in this work we have prepared four new members with various counter cations $\left(\mathrm{Ba}^{2+}\right)$ or anions $\left(\mathrm{OH}^{-}\right.$, $\left.\mathrm{Cl}^{-}\right)$and various iron valence. The versatile condensation of ortho-arsenites $\left(\mathrm{AsO}_{3}{ }^{2-}\right)$ into pyro- $\left(\mathrm{As}_{2} \mathrm{O}_{5}{ }^{4-}\right)$, rings or meta-arsenites favours the creation of efficient spacers, able to tune the magnetic dimensionality of the iron-based framework. These four new members cover from 0D (paramagnetic $\left.\mathrm{Ba}_{2} \mathrm{Fe}^{\mathrm{II}}\left(\mathrm{As}^{3+}{ }_{3} \mathrm{O}_{6}\right)_{2} \cdot \mathrm{H}_{2} \mathrm{O}\right), \quad 1 \mathrm{D} \quad(\mathrm{S}=5 / 2 \quad$ ladders in $\mathrm{Ba}_{2} \mathrm{Fe}_{2}{ }_{2}{ }^{\mathrm{III}}\left(\mathrm{As}_{2} \mathrm{O}_{5}\right)\left(\mathrm{AsO}_{3}\right)(\mathrm{OH})$ ), $2 \mathrm{D}$ (layers of $\mathrm{S}=5 / 2$ dimers in $\mathrm{Ba}_{2} \mathrm{Fe}_{2}{ }^{\mathrm{III}} \mathrm{O}\left(\mathrm{As}_{2} \mathrm{O}_{5}\right)_{2}$, up to $3 \mathrm{D}$ $\left(\mathrm{T}_{\mathrm{N}}=97 \mathrm{~K}\right.$ in $\mathrm{Fe}_{3}{ }^{2.66+}\left(\mathrm{As}_{2} \mathrm{O}_{5}\right)\left(\mathrm{AsO}_{3}\right) \mathrm{Cl}$ with charge ordering) topologies. Their magnetic properties are analysed by means of combined structural, experimental results and ab-initio calculations.
\end{abstract}




\section{INTRODUCTION}

Reactions involving iron oxide and trivalent $\mathrm{As}^{3+}$ cation are dominated by parasitic redox reactions ( $\rightarrow \mathrm{As}^{5+}$ oxidation or $\rightarrow \mathrm{As}^{0}$ reduction) and by the easy sublimation of $\mathrm{As}_{2} \mathrm{O}_{3}$ such that the solid state routes are poorly reported. For instance, in the case of $\mathrm{Co}^{2+}$, the first cobalt arsenite $\mathrm{CoAs}_{2} \mathrm{O}_{5}$ was reported lately, in 2008 as a by-product of $\mathrm{CoAs}_{2}{ }^{1}$ The enhanced reactivity of $\mathrm{As}_{2} \mathrm{O}_{3}$ with hydroxyl groups was demonstrated analysing the $\mathrm{Ln}_{2} \mathrm{O}-\mathrm{As}_{2} \mathrm{O}_{3}-\mathrm{Fe}_{2} \mathrm{O}_{3}\left(\mathrm{Ln}=\right.$ lanthanide) against $\mathrm{La}(\mathrm{OH})_{3}-\mathrm{As}_{2} \mathrm{O}_{3}-\mathrm{Fe}_{2} \mathrm{O}_{3}$ products, concluding that only $\mathrm{La}(\mathrm{OH})_{3}$ was capable of stabilizing the arsenide oxide which further formed parasymplesite mineral after oxidation in air $\left(\mathrm{Fe}_{3}\left(\mathrm{AsO}_{4}\right)_{2} \cdot 8\left(\mathrm{H}_{2} \mathrm{O}\right)\right)$. In contrast, in presence of $\mathrm{Ln}_{2} \mathrm{O}_{3}$ the arsenic oxide evaporated. ${ }^{2}$ It also highlights the arsenite to arsenate together with the ferrous to ferric oxidation well evidenced in prior reports of the $\mathrm{As}_{2} \mathrm{O}_{3}-\mathrm{FeO}$ binary system dominated by the $\mathrm{Fe}^{3+}\left(\mathrm{AsO}_{4}\right)$ scorodite type during mineral formation. ${ }^{3}$ It is relevant that iron presents the ideal redox properties for in situ $\mathrm{Fe}^{2+} \rightarrow \mathrm{Fe}^{3+}$ topotactic oxidation capable of intriguing structural alteration accompanied by $\mathrm{Fe}$ exsolution while preserving the iron-arsenate or iron phosphate framework. ${ }^{4,5}$ Rare examples of crystallization of As ${ }^{\mathrm{III}}$ iron oxides by solid state routes are reported, but mainly consist of high temperature rapid reaction (kinetic control) with a significant oxidation of As ${ }^{\text {III }}$, see for instance the arsenato-arsenite $\mathrm{Fe}^{3+}{ }_{2}\left[\mathrm{As}^{3+}\left(\mathrm{As}^{5+} \mathrm{O}_{4}\right)_{3}\right] .{ }^{6}$ Finally, most reported iron arsenites concern mineralogical samples obtained in natural conditions such as Schneiderhöhnite $\mathrm{Fe}^{2+} \mathrm{Fe}_{3}{ }^{3+} \mathrm{As}_{5} \mathrm{O}_{13}$, Tooeleite $\mathrm{Fe}_{6}\left(\mathrm{AsO}_{3}\right)_{4} \mathrm{SO}_{4}(\mathrm{OH})_{4} .4 \mathrm{H}_{2} \mathrm{O}$ or also Radovanite $\mathrm{Cu}_{2} \mathrm{Fe}^{3+}\left(\mathrm{As}^{5+} \mathrm{O}_{4}\right)\left(\mathrm{As}^{3+} \mathrm{O}_{2} \mathrm{OH}\right)_{2} \cdot \mathrm{H}_{2} \mathrm{O}$ (see Table 1 below for a complete list). ${ }^{7-9}$ It follows that chemical vapour transport (CVT) is a good synthetic route to emulate volcano gas precipitates help to the $\mathrm{As}_{2} \mathrm{O}_{3}$ or $\mathrm{AsCl}_{3}$ volatility. However, arsenates are prompt to condensate at the cold side, see the CVT synthesis of $\mathrm{Fe}^{2+}{ }_{3} \mathrm{Fe}^{3+}{ }_{4}\left(\mathrm{AsO}_{4}\right)_{6} \cdot{ }^{10,11}$ This complex chemical context justifies solvothermal syntheses as the method of choice to reproduce some of the solid precipitations from hot mineral-laden water heated by magma, and for the prospection of novel inorganic materials. So far, the incorporation of arsenite $\mathrm{AsO}_{3}{ }^{3-}$, phosphite $\mathrm{HPO}_{3}{ }^{2-}$ or selenite $\mathrm{SeO}_{3}{ }^{2-}$ groups is less studied, but is relevant for unusual low-D magnetic properties due to the poor magnetic connections across them, see for example the isolated $S=5 / 2$ dimers in $\mathrm{Fe}_{2}\left(\mathrm{SeO}_{3}\right)_{3}$ and $\mathrm{Fe}_{2}\left(\mathrm{HPO}_{3}\right)_{3}{ }^{12}$ Even more efficient spacers can be obtained further-combining large cations, e.g. $\mathrm{Ba}^{2+}$, and oxo-anions (phosphites, phosphates, arsenites, arsenates, etc), see for instance the nearly single chain magnet $\mathrm{BaCo}^{2+}{ }_{2}\left(\mathrm{As}^{3+}{ }_{3} \mathrm{O}_{6}\right)_{2} \cdot 2\left(\mathrm{H}_{2} \mathrm{O}\right)^{13}$ and the 2D-Ising ferromagnetism in $\mathrm{BaFe}_{2}\left(\mathrm{PO}_{4}\right)_{2}{ }^{14,15}$. In addition the $\mathrm{As}^{3+}$ electronic stereoactive lone pair (LP) is not only capable of easy poly-arsenite condensation, but may also directly coordinate transition metal ions, see $\mathrm{BaCo}\left(\mathrm{As}_{2} \mathrm{O}_{5}\right)$ with $\mathrm{Co}-\mathrm{As}$ bonds of $2.51 \AA .{ }^{16} \mathrm{Up}$ to now, only few inorganic iron arsenites, have been reported, as resumed in Table 1, which cover a broad field of structural dimensionalities offered by versatile assemblies of building $\mathrm{AsO}_{3}$ blocks into more or less polymerized diamagnetic spacers. We report in this work, four original members most of them part of the $\mathrm{BaO}-\mathrm{FeO}_{\mathrm{x}}-\mathrm{As}_{2} \mathrm{O}_{3}$ ternary system, listed as compounds (1) to (4) in the Table 1 and display ortho-, meta-, pyro-arsenites which template versatile structural and magnetic dimensionalities, from 0 to $3 \mathrm{D}$. 
Table 1. Reported iron arsenite compounds, with structural details and $\mathrm{AsO}_{3}$ condensation type.

\begin{tabular}{|c|c|c|c|c|c|}
\hline System & S.G. & $\begin{array}{l}a(\AA) \\
\alpha\left({ }^{\circ}\right)\end{array}$ & $\begin{array}{l}b(\AA) \\
\beta\left({ }^{\circ}\right)\end{array}$ & $\begin{array}{l}c(\AA) \\
Y\left({ }^{\circ}\right)\end{array}$ & V (Å3) \\
\hline $\begin{array}{c}\text { Fe redox/Arsenite } \\
\text { condensation }\end{array}$ & $\begin{array}{l}\text { Struct/magn. } \\
\text { Dimensionality }\end{array}$ & - & - & - & Ref. \\
\hline $\mathrm{Pb}_{4} \mathrm{Fe}\left(\mathrm{AsO}_{3}\right)_{2} \mathrm{Cl}_{4}\left(\mathrm{H}_{2} \mathrm{O}\right)_{2}$ & $P-1(2)$ & $\begin{array}{l}6.548(4) \\
96.2(1)\end{array}$ & $\begin{array}{l}10.243(8) \\
89.6(1)\end{array}$ & $\begin{array}{l}5.587(3) \\
97.7(1)\end{array}$ & $369.17(43)$ \\
\hline $\mathrm{Fe}^{2+} /$ ortho & OD / OD & - & - & - & [17] \\
\hline $\begin{array}{c}\mathrm{CuMn}_{14} \mathrm{Fe}(\mathrm{OH})_{6}\left(\mathrm{AsO}_{3}\right)_{5} \\
\left(\mathrm{SiO}_{4}\right)_{2}\left(\mathrm{AsO}_{4}\right)\end{array}$ & R3 (146) & $\begin{array}{l}8.223(4) \\
90\end{array}$ & $\begin{array}{l}8.223(4) \\
90\end{array}$ & $\begin{array}{l}37.4990(10) \\
120\end{array}$ & 2201.24 \\
\hline $\mathrm{Fe}^{3+} /$ ortho & OD / OD & - & - & - & [18] \\
\hline $\mathrm{CaFeSb}\left(\mathrm{As}_{2} \mathrm{O}_{7}\right)$ & | 41/a (88) & $\begin{array}{l}16.144(3) \\
90\end{array}$ & $\begin{array}{c}16.144(3) \\
90\end{array}$ & $\begin{array}{l}10.706(2) \\
90\end{array}$ & 2790.29 \\
\hline $\mathrm{Fe}^{3+} /$ pyro & OD / OD & - & - & - & [19] \\
\hline $\mathrm{Cu}_{2} \mathrm{Fe}\left(\mathrm{AsO}_{4}\right)\left(\mathrm{HAsO}_{3}\right)_{2} \cdot \mathrm{H}_{2} \mathrm{O}$ & $P$ n m a (62) & $\begin{array}{l}9.585(1) \\
90\end{array}$ & $\begin{array}{l}13.143(1) \\
90\end{array}$ & $\begin{array}{l}8.0884(7) \\
90\end{array}$ & \\
\hline $\mathrm{Fe}^{3+} /$ ortho & OD / OD & - & - & - & [9] \\
\hline $\mathrm{Fe}_{2}\left(\mathrm{As}\left(\mathrm{AsO}_{4}\right)_{3}\right.$ & $\mathrm{P} 6_{3}(173)$ & $\begin{array}{l}14.660(2) \\
90\end{array}$ & $\begin{array}{c}14.660(2) \\
90\end{array}$ & $\begin{array}{c}70.632(2) \\
120\end{array}$ & 1420.49 \\
\hline $\mathrm{Fe}^{3+} / \mathrm{As}^{3+}\left(\mathrm{As}^{5+} \mathrm{O}_{4}\right)_{3} \mathrm{TP}$ & $\begin{array}{l}\sim 0 D \text {, edge sharing } \\
\text { dimers }\end{array}$ & 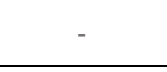 & 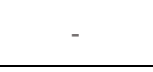 & 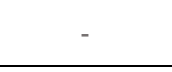 & {$[6]$} \\
\hline $\mathrm{FeFe}_{3}\left(\mathrm{As}^{3+} \mathrm{O}_{3}\right)\left(\mathrm{As}^{3+}{ }_{2} \mathrm{O}_{5}\right)_{2}$ & $P-1(2)$ & $\begin{array}{l}8.924(2) \\
59.91(2)\end{array}$ & $\begin{array}{l}10.016(3) \\
112.41(2)\end{array}$ & $\begin{array}{l}9.103(3) \\
81.69(2)\end{array}$ & 590.76 \\
\hline $\mathrm{Fe}^{2.75+} /$ ortho + pyro & $\begin{array}{l}\sim 2 \mathrm{D}, \text { corner and edge } \\
\text { sharing }\end{array}$ & - & - & - & [7] \\
\hline $\mathrm{FeFe}_{3}\left(\mathrm{As}^{3+} \mathrm{O}_{3}\right)\left(\mathrm{As}_{2}^{3+}{ }_{2} \mathrm{O}_{5}\right)$ & $P-1(2)$ & $\begin{array}{c}8.945(3) \\
62.942(5)\end{array}$ & $\begin{array}{c}10.022(3) \\
116.072(6)\end{array}$ & $\begin{array}{c}9.161(4) \\
81.722(6)\end{array}$ & 593.13 \\
\hline $\mathrm{Fe}^{2.75+} /$ ortho + pyro & $\begin{array}{l}\sim 2 \mathrm{D}, \text { corner and edge } \\
\text { sharing }\end{array}$ & 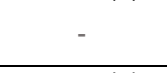 & 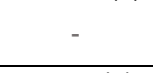 & 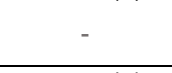 & [20] \\
\hline $\mathrm{PbFe}_{4}\left(\mathrm{As}^{3+}{ }_{5} \mathrm{O}_{11}\right)_{2}$ & A-1 (2) & $\begin{array}{l}10.426(4) \\
101.84(3)\end{array}$ & $\begin{array}{l}12.074(5) \\
100.21(3)\end{array}$ & $\begin{array}{l}18.349(8) \\
90.60(3)\end{array}$ & 2222.26 \\
\hline $\mathrm{Fe}^{3+} /$ pentamers & $\sim 2 \mathrm{D}$, edge sharing & - & - & - & [21] \\
\hline $\begin{array}{c}\mathrm{Fe}_{6}\left(\mathrm{As}^{3+} \mathrm{O}_{3}\right)_{4} \\
\left(\mathrm{SO}_{4}\right)(\mathrm{OH})_{4} \cdot 4 \mathrm{H}_{2} \mathrm{O}\end{array}$ & C $12 / m 1$ (12) & $\begin{array}{l}8.9575(1) \\
90\end{array}$ & $\begin{array}{l}6.4238(1) \\
96.032(1)\end{array}$ & $\begin{array}{l}9.7912(1) \\
90\end{array}$ & 560.28 \\
\hline $\mathrm{Fe}^{3+} /$ ortho & $\begin{array}{c}\sim 2 \mathrm{D}, \text { corner and edge } \\
\text { sharing }\end{array}$ & 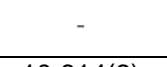 & คी०0 & - & [8] \\
\hline $\mathrm{Fe}_{2.38} \mathrm{Ti}_{0.54} \mathrm{O}_{2}\left(\mathrm{As}^{3+}{ }_{2} \mathrm{O}_{5}\right)$ & P 12 / /m 1 (11) & $\begin{array}{l}10.614(2) \\
90\end{array}$ & $\begin{array}{c}3.252(1) \\
108.95(2)\end{array}$ & $\begin{array}{c}8.945(1) \\
90\end{array}$ & 292.02 \\
\hline $\mathrm{Fe}^{2.5+} /$ pyro & $\begin{array}{l}\text { 3D with channels, corner } \\
\text { and edge sharing }\end{array}$ & - & $40770 / 0)$ & - & [22] \\
\hline $\begin{array}{c}\left(\mathrm{Fe}_{10.14} \mathrm{Zn}_{1.80}\right)\left(\mathrm{AsO}_{3}\right)_{6}(\mathrm{OH})_{6} \\
\left(\mathrm{As}_{1.536} \mathrm{Si}_{0.492} \mathrm{O}_{6}(\mathrm{OH})_{0.492}\right)\end{array}$ & P 63 m c (186) & $\begin{array}{l}12.773(2) \\
90\end{array}$ & $\begin{array}{c}12.773(2) \\
90\end{array}$ & $\begin{array}{c}5.051(1) \\
120\end{array}$ & 713.66 \\
\hline $\mathrm{Fe}^{2.6+} /$ ortho & $\begin{array}{c}\sim 3 \mathrm{D} \text { with channels edge } \\
\text { sharing }\end{array}$ & - & - & - & {$[23]$} \\
\hline $\mathrm{Ba}{ }_{2} \mathrm{Fe}\left(\mathrm{As}^{3+}{ }_{3} \mathrm{O}_{6}\right)_{2} \cdot \mathrm{H}_{2} \mathrm{O}$ & $P n m a(62)$ & $\begin{array}{c}17.9785(1) \\
90\end{array}$ & $\begin{array}{c}13.9388(1) \\
90\end{array}$ & $\begin{array}{l}5.9900(4) \\
90\end{array}$ & 1501.09 \\
\hline $\mathrm{Fe}^{2+} /$ meta- 3 rings & OD / OD & - & - & - & This work (1) \\
\hline $\begin{array}{c}\mathrm{BaFe}_{2}\left(\mathrm{As}_{2}^{3+} \mathrm{O}_{5}\right) \\
\left(\mathrm{As}^{3+} \mathrm{O}_{3}\right)(\mathrm{OH})\end{array}$ & $P n a 21$ (33) & $\begin{array}{c}17.9074(13) \\
90\end{array}$ & $\begin{array}{c}11.8434(8) \\
90\end{array}$ & $\begin{array}{l}6.9555(5) \\
90\end{array}$ & $1475.15(18)$ \\
\hline $\mathrm{Fe}^{3+} /$ ortho + pyro & $\begin{array}{c}\text { 1D double chains/ 1D } \\
\text { ladders }\end{array}$ & 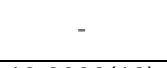 & - & - & This work (2) \\
\hline $\mathrm{Ba}_{2} \mathrm{Fe}_{2} \mathrm{O}\left(\mathrm{As}^{3+}{ }_{2} \mathrm{O}_{5}\right)_{2}$ & P b a m $(55$ & $\begin{array}{c}13.6083(18) \\
90\end{array}$ & $\begin{array}{c}7.3739(10) \\
90\end{array}$ & $\begin{array}{c}9.0121(12) \\
90\end{array}$ & $904.3(2)$ \\
\hline $\mathrm{Fe}^{3+}(\mathrm{SPP}) /$ pyro & $\begin{array}{l}\text { 2D layers/ 2D with } \\
\text { predominant dimers }\end{array}$ & - & - & - & This work (3) \\
\hline $\mathrm{Fe}_{3}\left(\mathrm{As}_{2} \mathrm{O}_{5}\right)\left(\mathrm{AsO}_{3}\right) \mathrm{Cl}$ & I 4/m c m (140) & $\begin{array}{l}8.6665(4) \\
90\end{array}$ & $\begin{array}{l}8.6665(4) \\
90\end{array}$ & $\begin{array}{l}16.107(2) \\
90\end{array}$ & $120.77(17)$ \\
\hline $\mathrm{Fe}^{2.66+} /$ ortho + pyro & 3D / 3D & - & - & - & This work (4) \\
\hline
\end{tabular}

\section{EXPERIMENTAL SECTION}

Generalities about the synthetic strategy: As emphasized in the introduction, the precipitation of transition metal arsenites depends on the redox and $\mathrm{pH}$ conditions, determining the final product $\left(\mathrm{E}^{0} / \mathrm{ESH} \mathrm{H}_{3} \mathrm{AsO}_{4} / \mathrm{H}_{3} \mathrm{AsO}_{3}=0.56 \mathrm{~V}\right)$. This is particularly important dealing with iron $\left(\mathrm{E}^{0} / \mathrm{ESH} \mathrm{Fe}^{3+} / \mathrm{Fe}^{2+}=0.77 \mathrm{~V}\right)$ whose main oxidation states in solvothermal media form a complex potential-pH diagram. Assuming that $\mathrm{As}$ and $\mathrm{Fe}$ species only interact while 
crystallizing in the solid, their respective Pourbaix diagram may guide the working conditions. A superposition of both simplified diagrams is represented on Fig. S1 pointing out strategical conditions keeping arsenite poly-groups for various iron oxidation states. Since many chemical reactions can occur in autogenous pressure hydrothermal conditions, at our level only postrationalization was attempted. To keep the $\mathrm{As}^{3+}$ based oxo-anions, hydrazine is used as reducing agent, however it is also a weak base which lowering the $\mathrm{pH}$ through two protonation stages. The $\mathrm{pH}$ control depends then on the choice of the metal precursor. Typically, one could apply the following reasoning for the 4 compounds listed below: compound (1) is a ferrous $\left(\mathrm{Fe}^{2+}\right)$ arsenite prepared from an initial $\mathrm{pH}=6-7$ solution after dissolution of the weak bases hydrazine and $\mathrm{As}_{2} \mathrm{O}_{5}$ and the weakly acid $\mathrm{FeCl}_{2}$. It falls in the broad window of stable ferrous arsenite in the acid to neutral $\mathrm{pH}$ region at sufficiently low potential. On the other hand, the concomitant preparation of 2 and 3 turned out to be poorly reproducible, in good agreement with the small window relevant for ferrous arsenites, stable at higher $\mathrm{pH}$. In our conditions we reached a $\mathrm{pH}$ of 9 using $\mathrm{KH}_{2}\left(\mathrm{AsO}_{4}\right)$ as precursor. One notes that the condensation of $\left(\mathrm{As}_{3} \mathrm{O}_{6}\right)^{3-}$ rings in compound 1 is achieved in acidic conditions compared to the ortho and pyro-arsenites of compounds 2 and 3 as expected. However, for compound (4) with mixed valence $\mathrm{Fe}^{+2.66}$ and prepared in ethanol as reducing solvent, such considerations on acido-basic conditions of reaction is hardly arguable, but a $\mathrm{pH}$ rather acidic can be expected from the used precursor, requiring thus a quite oxidizing media.

Detailed Conditions: $\mathrm{Ba}_{2} \mathrm{Fe}^{\mathrm{II}}\left(\mathrm{As}^{3+}{ }_{3} \mathrm{O}_{6}\right)_{2} \cdot \mathrm{H}_{2} \mathrm{O}$ (compound (1)) single crystals were synthetized from precursors $\mathrm{Ba}(\mathrm{OH})_{2} .8 \mathrm{H}_{2} \mathrm{O}(2.24 \mathrm{~g}), \mathrm{Fe}^{\mathrm{II}} \mathrm{Cl}_{2} .4 \mathrm{H}_{2} \mathrm{O}(1.39 \mathrm{~g})$ and $\mathrm{As}^{\mathrm{V}_{2}} \mathrm{O}_{5}$ (2.07g) (in 1:2:1.5 molar ratio, total mass $5 \mathrm{~g}$ ), with $\sim 8 \mathrm{~mL}$ of distilled water and hydrazine monohydrate $(65 \%)$ as reducing agent, in a $23 \mathrm{~mL}$ Teflon lined autoclave, heated 72 hours to $220{ }^{\circ} \mathrm{C}$, and then cooled down to room temperature within 200 hours. Some yellow transparent flake-like single crystal of the phase (size up to $0.2 \times 0.2 \times 0.03 \mathrm{~mm}$ ) were isolated from the mainly polycrystalline mixture.

$\mathrm{BaFe}_{2}\left(\mathrm{As}_{2} \mathrm{O}_{5}\right)\left(\mathrm{AsO}_{3}\right)(\mathrm{OH})$ (compound (2)) and $\mathrm{Ba}_{2} \mathrm{Fe}_{2} \mathrm{O}\left(\mathrm{As}_{2} \mathrm{O}_{5}\right)_{2}$ (compound (3)) crystals were initially found in the same batch, obtained under hydrothermal conditions from a mixture of $\mathrm{BaCl}_{2} .2 \mathrm{H}_{2} \mathrm{O}, \mathrm{FeCl}_{2} .4 \mathrm{H}_{2} \mathrm{O}$ and $\mathrm{KH}_{2} \mathrm{AsO}_{4}$ in a 1:2:3 ratio (total mass $=1 \mathrm{~g}$ ) with $\sim 7 \mathrm{~mL}$ of distilled water and $1 \mathrm{~mL}$ of hydrazine monohydrate $(65 \%)$ as reducing agent in a $23 \mathrm{~mL}$ Teflon lined autoclave. The reactor was heated 70 hours to $215{ }^{\circ} \mathrm{C}$ and cooled down to room temperature for 75 hours. The resulting sample contain thin light green needle like crystals of $\mathrm{Ba}_{2} \mathrm{Fe}_{2}\left(\mathrm{As}_{2} \mathrm{O}_{5}\right)\left(\mathrm{AsO}_{3}\right)(\mathrm{OH})$ (up to $1 \mathrm{~mm}$ long, $0.01 \mathrm{~mm}$ wide, yield about $65 \%$ ) and some dark green cubic like crystals of $\mathrm{Ba}_{2} \mathrm{Fe}_{2} \mathrm{O}\left(\mathrm{As}_{2} \mathrm{O}_{5}\right)_{2}$ (size up to $0.1 \times 0.1 \times 0.03 \mathrm{~mm}$, yield about $25 \%$ ). We were also able to prepare high purity polycrystalline phase (compound (2)) in a $23 \mathrm{~mL}$ Teflon lined autoclave from $\mathrm{BaCO}_{3}, \mathrm{FeCl}_{2} .4 \mathrm{H}_{2} \mathrm{O}$ and $\mathrm{As}_{2} \mathrm{O}_{3}$ in 1:2:1.5 ratio with $\sim 7 \mathrm{~mL}$ of distilled water and $1 \mathrm{~mL}$ of hydrazine monohydrate $(65 \%)$, heated 70 hours to $220{ }^{\circ} \mathrm{C}$ and then cooled down to room temperature in 100 hours $\mathrm{Fe}_{3}\left(\mathrm{As}_{2} \mathrm{O}_{5}\right)\left(\mathrm{AsO}_{3}\right) \mathrm{Cl}$ (compound (4)) crystals were grown by hydrothermal treatment of a mixture of $\mathrm{FeCl}_{2} .4 \mathrm{H}_{2} \mathrm{O}$ and $\mathrm{As}_{2} \mathrm{O}_{5}$ in stoichiometric proportion (total mass $=1 \mathrm{~g}$ ) and $8 \mathrm{~mL}$ of ethanol in a $23 \mathrm{~mL}$ Teflon lined autoclave, heated 24 hours to $180{ }^{\circ} \mathrm{C}$ and cooled down for 75 hours to room temperature. The resulting material was filtered, washed twice with hot water, rinsed with ethanol and dried in air. The sample consist of high-purity orange brownish cuboid-like single crystal of the phase (with dimensions about $0.15 \times 0.15 \times 0.6 \mathrm{~mm}$ ) that tend to form clumps and twinning, and residual $\gamma-\mathrm{Fe}_{2} \mathrm{O}_{3}$. Each batch was filtered, washed with hot water, rinsed with ethanol and dried in air. Sonication was used to separate crystals from the mixture. 


\section{Single-Crystal X-Ray Diffraction (XRD)}

Room-temperature single crystal XRD was carried out on a DUO-Bruker SMART diffractometer using Mo-K $\alpha$ radiation, with an APEX detector and a graphite monochromator. Intensities were extracted and corrected from the Lorentz-polarization factor through the SAINT program. A multiscan absorption correction was applied using SADABS. Structures were solved using Superflip and refined using JANA2006. Hydrogens were located on Fourierdifference maps.

\section{IR and UV-visible Spectroscopies}

Spectroscopies were perform on grinded materials of compounds (2) and (4), to date we have not been able to produce enough amount of compound (1) and (3) to perform satisfactory measurements.

Infrared spectroscopy (IR) were performed on a Perkin Elmer Spectrum 2 device, equipped with a diamond attenuated total reflectance (ATR) accessory. Samples were measured between $4000 \& 400 \mathrm{~cm}^{-1}$. No ATR corrections were applied on the spectrum.

UV-visible measurement was performed on a Perkin Elmer Precisely Lambda 650 Spectrometer devices, using an STD Detector module \& HARRICK Praying Mantis Sampling Kit. The measurements were done between $900 \& 250 \mathrm{~nm}$.

Scanning Electron Microscope (SEM) and Energy-dispersive X-ray spectroscopy (EDS) SEM and EDS analysis were performed on small amount of crystals placed on a carbon tape and graphited to avoid surfaces charging. Samples were introduced in a field-emission gun Scanning Electron Microscope (SEM) HITACHI S4700 device equipped with and Energy-dispersive X-Ray detector, operating at $20 \mathrm{kV}$ electron beam energy and the EDS analysis result is given from the average of several different points acquisitions.

\section{Magnetic Measurements}

The magnetic properties and specific heat measurements were measured on a Physical Property Measurement System (PPMS) Dynacool (9 T) system from Quantum Design. Magnetic measurements were perform using grinded polycrystalline phase for compound (2) $\left(\mathrm{Ba}_{2} \mathrm{Fe}_{2}\left(\mathrm{As}_{2} \mathrm{O}_{5}\right)\left(\mathrm{AsO}_{3}\right)(\mathrm{OH})\right)$, sorted single crystal of compound (3) $\left(\mathrm{Ba}_{2} \mathrm{Fe}_{2} \mathrm{O}\left(\mathrm{As}_{2} \mathrm{O}_{5}\right)_{2}\right)$, and grinded polycrystalline phase for compound (4) $\left(\mathrm{Fe}_{3} \mathrm{As}_{3} \mathrm{O}_{8} \mathrm{Cl}\right)$. Typical measurements were performed using zero field cooling (ZFC) and field cooling (FC) procedures under various fields. Magnetization versus $\mathrm{H}$ were measured between -9 and $9 \mathrm{~T}$ at various temperatures. Specific heat measurements were carried out at $0 \mathrm{~T}$ using either deposited single-crystal (compound (2) and (3)), or grinded material pressed into a pellet (compound (4)).

\section{Density Functional Theory (DFT) Calculations - Computational Methods}

DFT calculations were carried using the Vienna ab initio simulation package (VASP) by employing the projector augmented wave (PAW) method and the generalized gradient approximation of Perdew, Burke and Ernzerhof (PBE) for the exchange-correlation functionals. ${ }^{24,25} \mathrm{GGA}+U$ calculations were employed with $\mathrm{U}=4$ to 6 or $7 \mathrm{eV}$. The plane wave cutoff energies of $400 \mathrm{eV}$ and the threshold of self-consistent-field energy convergence of $10^{-6} \mathrm{eV}$ were used, with $82 / 100 / 39 / 102 k$ points in the irreducible Brillouin Zone for $\mathrm{Ba}_{2} \mathrm{Fe}\left(\mathrm{As}_{3} \mathrm{O}_{6}\right)_{2} \cdot \mathrm{H}_{2} \mathrm{O}, \mathrm{BaFe}_{2}\left(\mathrm{As}_{2} \mathrm{O}_{5}\right)\left(\mathrm{AsO}_{3}\right)(\mathrm{OH}), \mathrm{Ba}_{2} \mathrm{Fe}_{2} \mathrm{O}\left(\mathrm{As}_{2} \mathrm{O}_{5}\right)_{2}$ and $\mathrm{Fe}_{3}\left(\mathrm{As}_{2} \mathrm{O}_{5}\right)\left(\mathrm{AsO}_{3}\right) \mathrm{Cl}$ respectively. The energies of selected ordered spin states are expressed using the spin 
Hamiltonian,

$\widehat{H}=-\sum_{i<j} J_{i j} \hat{S}_{i} \cdot \hat{S}_{j}$, where $\mathrm{J}_{i j}$ corresponds to the exchange parameters between the spin sites $i$ and $j$, extracted by equating the relative energies of the selected ordered magnetic states to the corresponding energies determined from the GGA+U calculations, see Fig. and Tables S5 for the details of the selected magnetic configurations.

\section{RESULTS AND DISCUSSION}

\section{Isolated magnetic units / $\mathrm{As}_{3} \mathrm{O}_{6}$ rings in $\mathrm{Ba}_{2} \mathrm{Fe}^{\mathrm{II}}\left(\mathrm{As}^{3+}{ }_{3} \mathrm{O}_{6}\right)_{2} . \mathrm{H}_{2} \mathrm{O}$}

Structural Analysis : $\mathrm{Ba} 2 \mathrm{Fe}\left(\mathrm{As}_{3} \mathrm{O}_{6}\right)_{2} \cdot \mathrm{H}_{2} \mathrm{O}$ crystallographic structure was refined in a orthorhombic Pna2 ${ }_{1}$ (33) space group with $a=17.9074(13) \AA, b=11.8434(8) \AA$ and $c=6.9555(5) \AA$ with a final $\mathrm{R}=5.14 \%$ (72 parameters). This non centrosymmetric space group was preferred, solving the problem of water molecule disorder inherent to the refinement in the centrosymmetric Pbam (55) space group using the same cell $(\mathrm{R}=6.11 \%$ and 71 parameters). However to avoid the artificial increase of the number of refined parameters the rigid framework was constrained centrosymmetric, while only the water molecule breaks the center of symmetry. Results of the refinement can be found in Table 2 below, while details related to crystallographic refinement such as thermal parameters, pertinent distances and bond valences sum calculations can be found in Tables $S 2(a, b, c)$. The structure is built from the stacking of $\mathrm{Ba}_{2} \mathrm{Fe}\left(\mathrm{As}_{3} \mathrm{O}_{6}\right)_{2}$ layers along $a$ axis. These layers are built from isolated $\mathrm{Fe}^{3+} \mathrm{O}_{6}$ octahedra connected by $\mathrm{As}_{3}{ }^{3+} \mathrm{O}_{6}$ crown: each octahedra is connected to six other ones within the layers by O-As-O-As-O bridges, forming a pseudo-hexagonal lattice, see Fig. 1(a,b). One need to note that these exact $\mathrm{As}_{3}{ }^{3+} \mathrm{O}_{6}$ rings are rather rare, to the best of our knowledge are so far only found in the case of $\mathrm{Cu}_{2}\left(\mathrm{CH}_{3} \mathrm{COO}\right) \mathrm{As}_{3} \mathrm{O}_{6}$ hybrid structure and the vitreous $\mathrm{As}_{2} \mathrm{O}_{3}$, which makes compound (1) an intriguing case. ${ }^{26}$

The shortest Fe-Fe intralayer distance is equal to 6.8674(4) $\AA$, with $\mathrm{Ba}^{2+}$ cations occupying this vacant space (in details, $\mathrm{Ba}^{2+}$ stand above the centre of the $\mathrm{As}_{3}{ }^{3+} \mathrm{O}_{6}$ crown). The two shortest Fe-Fe interlayer distances are equal to 8.95-9.11 $\AA$, offering no significant magnetic exchange paths. It was validated after DFT-calculations of the two more significant exchange couplings, $\mathbf{J}_{1}$ (intralayer exchange, assuming a single type of distance) and $\mathbf{J}_{2}$ (shortest $\mathrm{Fe}-\mathrm{Fe}$ interlayer distance). It returns $\mathrm{J}_{1}=+0.23 \mathrm{~K}(\mathrm{AFM})$ and $\mathrm{J}_{2}=-0.14 \mathrm{~K}(\mathrm{FM})$, see Table $\mathrm{S} 4 \mathrm{a}$ for calculated relatives energies of the four selected configurations (represented Fig. S4b). These values are negligible, making compound (1) a paramagnet. The interlayers space is occupied by water molecule and $\mathrm{As}_{3}{ }^{3+} \mathrm{O}_{6}$ lone pair pointing toward the interlayers space, see Fig. 1c, as determined from the Electron localization function (ELF) obtained from the DFT calculations. This weakly bonded negatively charged interleave gives a Van der Waals (VDW) character to this phase similarly to the recent report of layered VDW- $\mathrm{Pb}_{4} \mathrm{Ln}_{2} \mathrm{O}_{7}$ series $(\mathrm{Ln}=\mathrm{La}, \mathrm{Gd}, \mathrm{Sm}, \mathrm{Nd})$ with $\mathrm{Pb}$ and oxygen only decorating the layer surface. ${ }^{27} \mathrm{~A}$ representation of the $\mathrm{As}^{3+}$ lone-pair as determined from ELF calculations for the three other compounds can be found in Fig. S2m. 
Table 2. Crystallographic data and Structure Refinement parameters for $\mathrm{Ba}_{2} \mathrm{Fe}\left(\mathrm{As}_{3} \mathrm{O}_{6}\right)_{2} . \mathrm{H}_{2} \mathrm{O}$, $\mathrm{BaFe}_{2}\left(\mathrm{As}_{2} \mathrm{O}_{5}\right)\left(\mathrm{AsO}_{3}\right)(\mathrm{OH}), \mathrm{Ba}_{2} \mathrm{Fe}_{2} \mathrm{O}\left(\mathrm{As}_{2} \mathrm{O}_{5}\right)_{2}$ and $\mathrm{Fe}_{3}\left(\mathrm{As}_{2} \mathrm{O}_{5}\right)\left(\mathrm{AsO}_{3}\right) \mathrm{Cl}$ single crystals at room temperature (left to right).

\begin{tabular}{|c|c|c|c|c|}
\hline Crystal Data (T = $293 \mathrm{~K}$ ) & Compound (1) & Compound (2) & Compound (3) & Compound (4) \\
\hline Formula & $\mathrm{Ba} 2 \mathrm{Fe}(\mathrm{As} 3 \mathrm{O} 6) 2 . \mathrm{H} 2 \mathrm{O}$ & $\mathrm{BaFe} 2(\mathrm{As} 2 \mathrm{O} 5)(\mathrm{AsO})(\mathrm{OH})$ & $\mathrm{Ba} 2 \mathrm{Fe} 2 \mathrm{O}(\mathrm{As} 2 \mathrm{O} 5) 2$ & $\mathrm{Fe} 3(\mathrm{As} 2 \mathrm{O} 5)(\mathrm{AsO} 3) \mathrm{Cl}$ \\
\hline Molar weight $(\mathrm{g} / \mathrm{mol})$ & 990.1 & 1237.6 & 862.1 & 555.8 \\
\hline Symmetry & Orthorhombic & Orthorhombic & Tetragonal & Triclinic \\
\hline Space group & $\mathrm{P} n$ a $2_{1}(33)$ & P b a m (55) & I 4/m c m (140) & $P-1(2)$ \\
\hline Unit cell $(\stackrel{A}{)})$ and angle $\left(^{\circ}\right)$ & $a=17.9074(13)$ & $a=13.6083(18)$ & $a=8.6665(4)$ & $a=5.5346(12) \quad \alpha=72.401(12)$ \\
\hline & $b=11.8434(8)$ & $b=7.3739(10)$ & $c=16.107(2)$ & $b=8.5292(19) \quad \beta=89.596(13)$ \\
\hline & $c=6.9555(5)$ & $c=9.0121(12)$ & & $c=9.626(2) \quad V=78.203(13)$ \\
\hline Volume $\left(\AA^{3}\right)$ & $1475.15(18)$ & $904.3(2)$ & $120.77(17)$ & $423.25(17)$ \\
\hline Z & 4 & 2 & 4 & 2 \\
\hline \multicolumn{5}{|l|}{ Data collection } \\
\hline $\begin{array}{l}\text { Equipment } \\
\lambda(\text { Mo Ka }(\AA)\end{array}$ & $\begin{array}{l}\text { Bruker DUO } \\
0.71073\end{array}$ & $\begin{array}{l}\text { Bruker DUO } \\
0.71073\end{array}$ & $\begin{array}{l}\text { Bruker DUO } \\
0.71073\end{array}$ & $\begin{array}{l}\text { Bruker DUO } \\
0.71073\end{array}$ \\
\hline Density calc. $\left(\mathrm{g} / \mathrm{cm}^{3}\right)$ & 4.4579 & 4.545 & 4.7330 & 4.3608 \\
\hline Color & Yellow & Light Green / Yellow & Dark green & Orange / Brownish \\
\hline$\theta(\min -\max )\left(^{\circ}\right)$ & $2.06-28.4$ & $2.26-26.02$ & $2.53-34.67$ & $2.22-33.3$ \\
\hline$\mu(\mathrm{mm}-1 ;$ for $\lambda \mathrm{Ka}=0,71073 \AA)$ & 19.668 & 18.393 & 19.679 & 17.044 \\
\hline $\mathrm{R}_{\text {int }}(\%)$ & 8.01 & 15.36 & 3.46 & 5.84 \\
\hline Recording reciprocal space & $-25 \leq h \leq 26$ & $-16 \leq h \leq 12$ & $-13 \leq h \leq 13$ & $-7 \leq \mathrm{h} \leq 7$ \\
\hline & $-17 \leq \mathrm{k} \leq 17$ & $-7 \leq k \leq 9$ & $-13 \leq k \leq 13$ & $-13 \leq k \leq 12$ \\
\hline & $-10 \leq I \leq 10$ & $-10 \leq \mid \leq 10$ & $-25 \leq 1 \leq 25$ & $-13 \leq I \leq 14$ \\
\hline $\mathrm{N}$ of measured reflections & 2667 & 886 & 721 & 2259 \\
\hline $\begin{array}{l}\mathrm{N} \text { of independant reflections } \\
(I>3 \sigma(I)\end{array}$ & 2083 & 363 & 667 & 1601 \\
\hline $\begin{array}{l}\text { Crystal dimension }(\mu \mathrm{m}) \\
\text { Shape }\end{array}$ & $\begin{array}{l}206 \times 30 \times 25 \\
\text { Needle }\end{array}$ & $\begin{array}{l}10 \times 10 \times 1000 \\
\text { Needle }\end{array}$ & $\begin{array}{l}50 \times 50 \times 10 \\
\text { Cubic }\end{array}$ & $\begin{array}{l}150 \times 150 \times 600 \\
\text { Square plate }\end{array}$ \\
\hline \multicolumn{5}{|l|}{ Refinement } \\
\hline $\mathrm{N}$ of refined parameters & 72 & 56 & 30 & 100 \\
\hline Ref. method, program & Least square on $\mathrm{F}$ & Least square on $\mathrm{F}$ & Least square on $\mathrm{F}$ & Least square on $\mathrm{F}$ \\
\hline Weighting scheme & Unit & Sigma & sigma & sigma \\
\hline $\mathrm{R}_{1}(\mathrm{~F})[\mathrm{I}>3 \sigma(\mathrm{I})] / \mathrm{R}_{1}\left(\mathrm{~F}^{2}\right)[\mathrm{All}, \%]$ & $5.14 / 6.67$ & $4.91 / 16.20$ & $1.34 / 1.57$ & $4.24 / 7.16$ \\
\hline$w^{2}\left(F^{2}\right)[I>3 \sigma(I)] / w R 2\left(F^{2}\right)[A l l, \%]$ & $6.29 / 7.00$ & $4.79 / 6.77$ & $1.79 / 1.83$ & $4.77 / 4.98$ \\
\hline GOF & 0.97 & 1.09 & 1.17 & 1.75 \\
\hline Max/min res. elec. density $\left(\mathrm{e}^{-} / \AA^{3}\right)$ & $2.94 /-2.48$ & $4.42 /-3.69$ & $0.42 /-0.42$ & $1.43 /-1.61$ \\
\hline Ref. extinction coeff. & None & 0.04148 & 0.004175 & 0.000319 \\
\hline
\end{tabular}

\section{Disconnected ladders, ortho- and pyro-arsenites in $\mathrm{BaFe}_{2}\left(\mathrm{As}_{2} \mathrm{O}_{5}\right)\left(\mathrm{As}_{\mathrm{S}} \mathrm{O}_{3}\right)(\mathrm{OH})$}

Structural Analysis: $\mathrm{BaFe}_{2}\left(\mathrm{As}_{2} \mathrm{O}_{5}\right)\left(\mathrm{AsO}_{3}\right)(\mathrm{OH})$ crystallizes in the orthorhombic Pbam (55) space group, with unit cell parameters $a=13.6080(13) \AA, b=7.3733(7) \AA$ and $c=9.0128(8) \AA$ and was refined to a final $\mathrm{R}_{\mathrm{obs}}=4.91 \%, \mathrm{wR}_{\mathrm{obs}}=4.79 \%$. The $\mathrm{H}$ position was located by Fourier difference maps next to O6 oxygen, forming hydroxide groups confirmed by infrared spectroscopy, discussed later, see Fig. 2a. The crystal structure is built of $\mathrm{Fe}^{3+} \mathrm{O}_{5} \mathrm{OH}$ octahedra which are corner shared into chains running along the $b$ axis. The Fe-O3-Fe angle is $130.5^{\circ}$ with a Fe-Fe distances of 3.691(1) $\AA$. In the $b c$ plane, chains are connected two by two into ladders by (O5-O6) which creates perpendicular rungs with $\mathrm{Fe}-\mathrm{Fe}$ distance of 3.104(1) $\AA$, see Fig. 1d. In plane, the chains are separated by $\left(\mathrm{As}^{3+}{ }_{2} \mathrm{O}_{5}\right)^{2-}$ pyro-arsenite groups, each $\mathrm{As}^{3+}$ center being bidentate with two corner-sharing octahedra from the ladder legs. Along the $a$-axis, the layers are separated by the pyro-arsenite lone pairs and by those of extra $\mathrm{AsO}_{3}$ groups chelating the ladders, see Fig. 1e. Finally, the $\mathrm{Ba}^{2+}$ cations occupy the site available in the $a c$ layers as shown Fig. 1f. In the $a b$ planes, the shortest Fe-Fe distances between two ladders is 5.909(1) $\AA$. Between two layers we find the shorted Fe-Fe distances of 6.619(1) $\AA$. Details regarding XRD collection and crystallographic refinement parameters are given in Table 2. The coordinates, thermal displacements and selected bond distances are shown in Tables S2(d,e,f). 
The refined formula $\mathrm{Ba}_{2} \mathrm{Fe}_{2}\left(\mathrm{As}_{2} \mathrm{O}_{5}\right)\left(\mathrm{AsO}_{3}\right)(\mathrm{OH})$ is in good agreement with the EDS analysis of crystals, leading to an average $\mathrm{Ba} / \mathrm{Fe} / \mathrm{As}$ ratio of 1.01/1.96/2.91, obtained from the acquisition of several points, see Fig. S3 (top).

a.

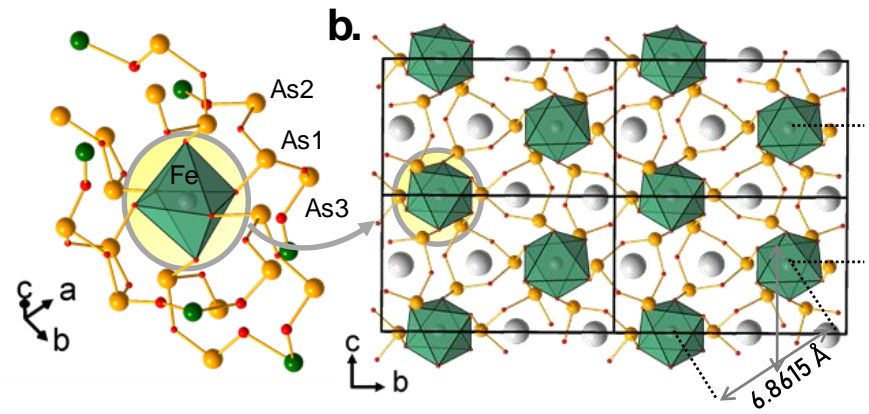

c.

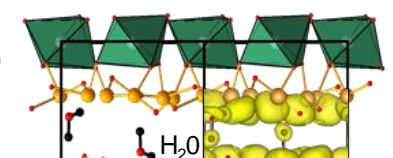

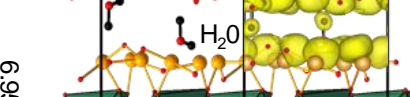

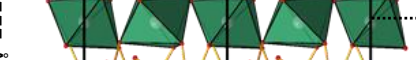

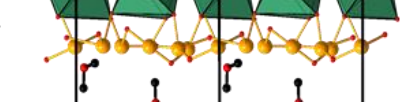

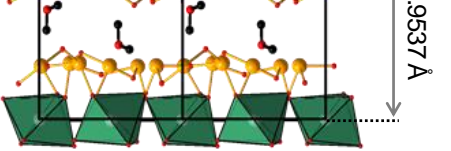

$\stackrel{\mathrm{L}}{\mathrm{c}}$

d.
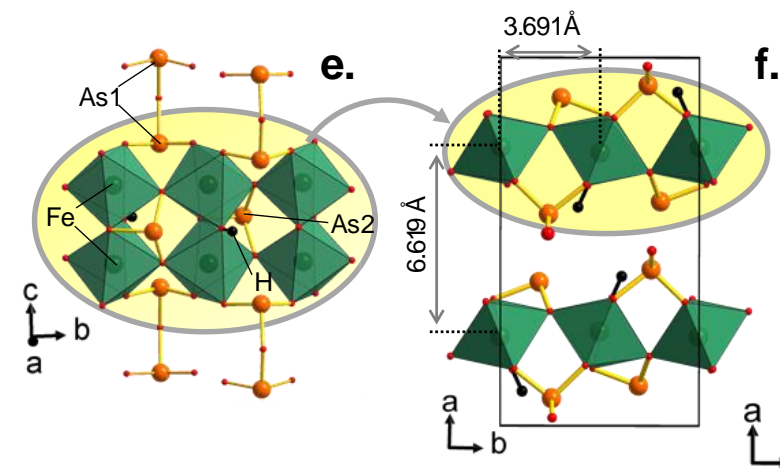

f.

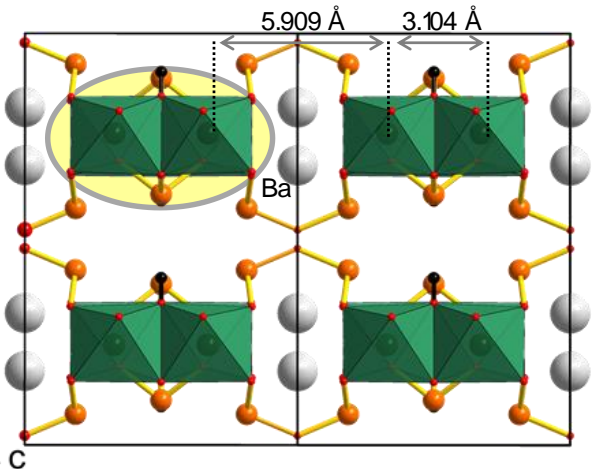

g.

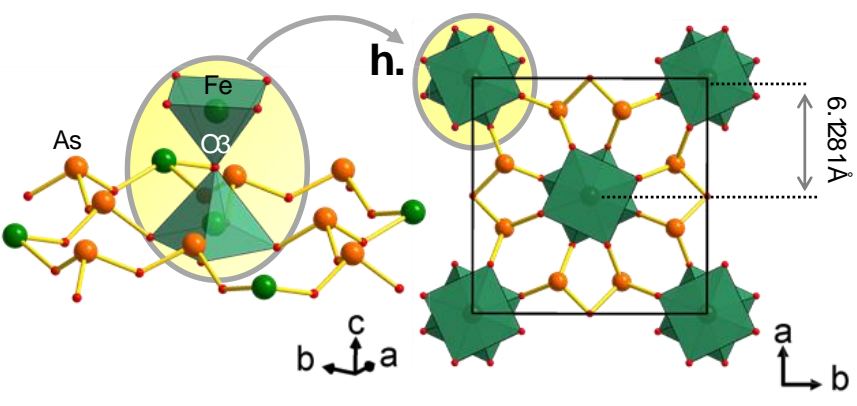

i.
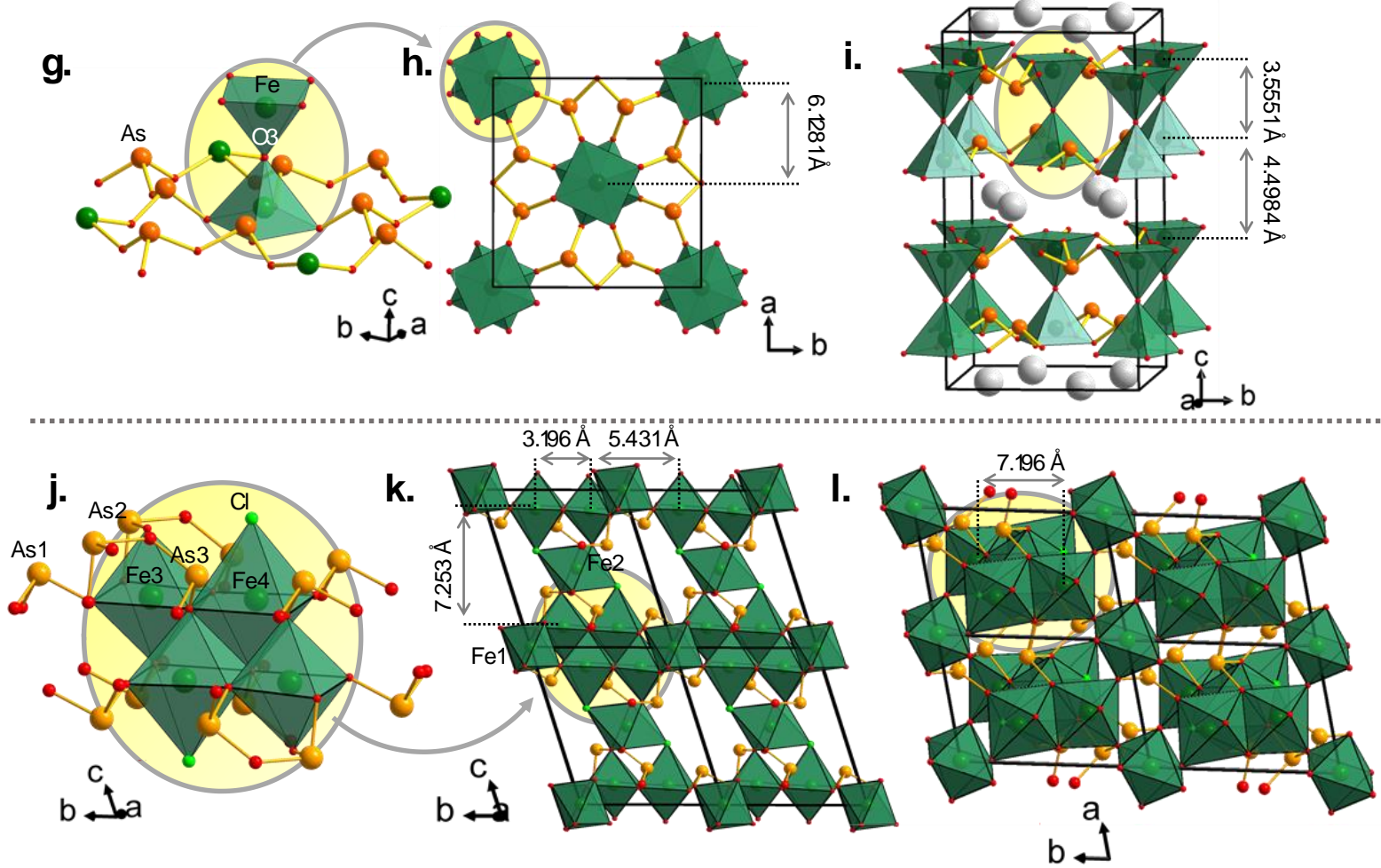
Fig. 1. Crystal structure: Three specific projection of the crystal structures with view of the magnetic units for $(a, b, c) \quad \mathrm{Ba}_{2} \mathrm{Fe}\left(\mathrm{As}_{3} \mathrm{O}_{6}\right)_{2} \cdot \mathrm{H}_{2} \mathrm{O} \quad(d, e, f,) \quad \mathrm{BaFe}_{2}\left(\mathrm{As}_{2} \mathrm{O}_{5}\right)\left(\mathrm{AsO}_{3} \mathrm{OH}\right), \quad(g, h, i) \quad \mathrm{Ba}_{2} \mathrm{Fe}_{2} \mathrm{O}\left(\mathrm{As}_{2} \mathrm{O}_{5}\right)_{2} \quad$ and $\quad(j, k, l)$ $\mathrm{Fe}_{3}\left(\mathrm{As}_{2} \mathrm{O}_{5}\right)\left(\mathrm{AsO}_{3}\right) \mathrm{Cl}$.

Spectroscopic characterization: The infrared spectra is displayed in Fig. S2n, with bands attribution.. The presence of hydroxides is confirmed by a stretching and in plane deformation modes seen around 3435 and $1415 \mathrm{~cm}^{-1}$ respectively. The UV-visible spectra is given Fig. 2 (grey plot) and show a strong absorbance peak centred around $300 \mathrm{~nm}$ (violet absorption) in great agreement with the yellow-greenish colour of the sample. From this measurement, the optical gap is found to be about $2.8 \mathrm{eV}$.

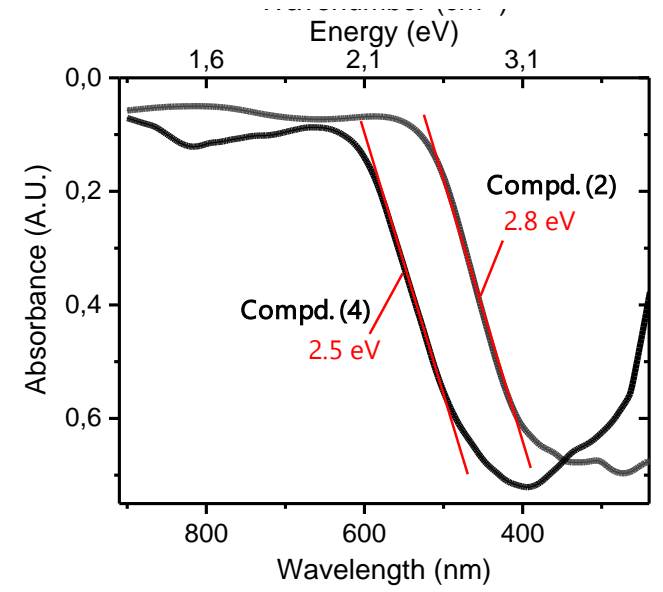

Figure 2. Spectroscopies: UV Visible spectra for $\mathrm{BaFe}_{2}\left(\mathrm{As}_{2} \mathrm{O}_{5}\right)\left(\mathrm{AsO}_{3}\right)(\mathrm{OH})$ (compound (2)) and $\mathrm{Fe}_{3}\left(\mathrm{As}_{2} \mathrm{O}_{5}\right)\left(\mathrm{As} \mathrm{O}_{3}\right) \mathrm{Cl}$ (compound (4)).

Magnetic exchanges: Contrarily to the compound (1), condensed magnetic units emerge from the crystal structure. The main identified magnetic exchanges for $\mathrm{BaFe}_{2}\left(\mathrm{As}_{2} \mathrm{O}_{5}\right)\left(\mathrm{AsO}_{3}\right)(\mathrm{OH})$ are shown Fig. 3a. We performed the exchange calculations $\mathrm{J}$ with $\mathrm{GGA}+\mathrm{U}$ for $\mathrm{U}=4$ and $6 \mathrm{eV}$. Three main magnetic exchange paths $\mathbf{J}_{1}, \mathbf{J}_{2}, \mathbf{J}_{\mathrm{d}}$ are expected within the ladders shown Fig. 3a, with $\mathrm{J}_{\text {inter }}$ and $\mathrm{J}_{3}$ couplings between the chains expected very weak from crystallographic consideration. The super-exchange (SE) $\mathrm{J}_{1}$ along the ladder legs is expected dominant due to the $\mathrm{Fe}-\mathrm{O}-\mathrm{Fe}$ angle of $130.6^{\circ}$, compared to $\mathrm{J}_{2}$ along the ladder rungs with $\mathrm{Fe}-\mathrm{O}-\mathrm{Fe}=96.2^{\circ}$ and $99.3^{\circ}$ close to orthogonal. Finally within the ladders $\mathrm{J}_{\mathrm{d}}$ correspond to the diagonal super-super exchange paths with one component associated to the dihedral $\angle \mathrm{Fe}-\mathrm{O}-\mathrm{O}-\mathrm{Fe}$ angle of $19^{\circ}$. Between the ladders in the $b c$ layers the connections $\left(\mathrm{d}_{\mathrm{Fe}-\mathrm{Fe}}=5.91 \AA\right)$ are achieved by $\mathrm{Fe}-\mathrm{O}$ (As)-O-(As)-O-bridges, this is expected to be very low. For $\mathrm{U}=6 \mathrm{eV}$ we found $\mathrm{J}_{1}=+28.56 \mathrm{~K}$ $(\mathrm{AFM}), \mathrm{J}_{2}=+6.57 \mathrm{~K}(\mathrm{AFM})$ and $\mathrm{J}_{\mathrm{d}}=-3.29 \mathrm{~K}(\mathrm{FM}), \mathrm{J}_{4} \sim 0, \mathrm{~J}_{\text {inter }}=+0.69 \mathrm{~K}(\mathrm{AFM})$. Along the $a$ axis, in between the layers $\left(\mathrm{d}_{\mathrm{Fe}-\mathrm{Fe}}=6.98 \AA\right.$ ), there is no orbital overlap susceptible of electron transfer, such that $S=5 / 2$ chains arranged in isolated ladders emerge, and only the magnetic anisotropy or weak dipole-dipole magnetic exchanges would induce magnetic ordering. Details related to selected magnetic configurations, corresponding calculated relative energies, and geometrical aspects of exchange paths can be found in Fig. and Tables S4(c,d,e).

Magnetic Characterizations: The best sample for the investigation of the magnetic properties consisted of $2.6 \mathrm{mg}$ of by hand isolated needles, but containing a minor but significant amount of a second phase, probably surficial, which develops a FM-like hysteresis already at $300 \mathrm{~K}$, see Fig. S5b, that we attributed to residual $\mathrm{Fe}_{3} \mathrm{O}_{4}$ or $\mathrm{Fe}_{2} \mathrm{O}_{3}$. After a preliminary alignment of this phase at $9 \mathrm{~T}$, this contribution can be considered as temperature independent and was 
subtracted from the $\mathrm{M}(\mathrm{T})$ data collected at $0.5 \mathrm{~T}$. The validity of this preliminary correction was confirmed by the resulting effective moment of $5.65 \mu_{\mathrm{B}} / \mathrm{Fe}^{3+}$ between 300 and $400 \mathrm{~K}$, in high agreement with the $5.92 \mu_{\mathrm{B}} / \mathrm{Fe}$ expected for $\mathrm{Fe}^{3+}$. After corrections of the paramagnetic tail prominent below $8 \mathrm{~K}$, see Fig. 3b, the intrinsic susceptibility was fitted using the BonnerFischer law for classical Heisenberg $S=5 / 2$ spins:

$$
\chi_{\text {chain }}(T)=\frac{C}{T} \times \frac{1+u(T)}{1-u(T)} \quad(\text { equation } 1)
$$

where $\mathrm{u}(\mathrm{T})=$ coth $\mathrm{W}-1 / \mathrm{W}$, with $\mathrm{W}=\mathrm{J}_{\text {chain }} \mathrm{S}(\mathrm{S}+1) / \mathrm{k}_{\mathrm{B}} \mathrm{T}$ and the Curie constant $\mathrm{C}=\mathrm{N}_{\mathrm{A}} \mathrm{g}^{2} \mu \mathrm{b}^{2} \mathrm{~S}(\mathrm{~S}+1) / 3 \mathrm{k}_{\mathrm{B}}$.

To allow interchain spin-exchange interaction, we utilized the molecular field extension for the susceptibility in the paramagnetic regime given below, where the Curie-Weiss temperature $\theta_{\text {inter }}$ is given by its standard mean field approximation, with $\mathrm{z}=1$, taking into account the calculated $\mathrm{J}_{2}$ value.

$$
\begin{aligned}
& \chi_{\text {chain }}^{M F}=\frac{\chi_{\text {chain }}(T)}{1-\theta_{\text {inter }}\left[\frac{\chi_{\text {chain }}(T)}{C}\right]}(\text { equation } 2) \\
& \theta_{\text {inter }}=\frac{z S(S+1)}{3} \frac{J}{k_{B}}(\text { equation } 3)
\end{aligned}
$$

The $\chi(\mathrm{T})$ broadening below $100 \mathrm{~K}$ is assigned to the thermal effect of the interaction between the chains in-plane. The best fit was obtained above $78 \mathrm{~K}$ for which $\mathrm{J}_{\text {chain }}$ should prevail. was performed using $\mathrm{g}=2$ and an extra temperature independent term $\chi_{0}$ in order to adjust our preliminary corrections of the FM impurity. The results are in good agreement with our DFT calculations, i.e. AFM $\mathrm{J}_{\text {chain }}=29.81(5) \mathrm{K}$ against $28.56 \mathrm{~K}_{\mathrm{DFT}}$ and ${ }_{\mathrm{AFM}} \mathrm{J}_{\text {inter }}=6.2(4) \mathrm{K}$ against AFM $J_{2}$ and ${ }_{F M} J_{d}=6.57$ and $3.29 \mathrm{~K}$ by DFT, respectively. The ferromagnetic $J_{d}$ has the tendency to reinforce the AFM exchange between the chains, it may be accounted in the over-estimation of $J_{\text {inter }}$ after fitting. The heat capacity measured on single crystals deposited on the sample holder confirms the absence of any-ordering at low temperature, see $\mathrm{C}_{\mathrm{p}} / \mathrm{T}(\mathrm{T})$ on Fig. $3 \mathrm{c}$, returning a pronounced $1 \mathrm{D}$ character to the compound (1).

Besides organic ligands as spacers, such as in the well-known TMMC $\left(\left(\mathrm{CH}_{3}\right)_{4} \mathrm{~N}\left(\mathrm{MnCl}_{3}\right)\right)$ which has been the paradigm of a Heisenberg AFM classical $S=5 / 2$ chain ${ }^{28}$ or the recent $\mathrm{FeF}_{3}\left(4,4^{\prime}\right.$-bpy) $\left(4,4^{\prime}\right.$-bpy $=4,4^{\prime}$-bipyridyl $),{ }^{29}$ all-inorganic $\mathrm{S}=5 / 2\left(\mathrm{Mn}^{2+}, \mathrm{Fe}^{3+}\right)$ chain topology is relatively rare, with most relevant examples listed in ref 33 . Thus the magnitude of $\mathbf{J}_{1}$ deserves further attention and appears much larger than in the majority of systems which exhibit edge sharing octahedra along the $1 \mathrm{D}$ units such as $\mathrm{CuMnVO}_{4}\left(\mathrm{~J}=-7 \mathrm{~K}, \mathrm{Mn}-\mathrm{O}-\mathrm{Mn}=94.6^{\circ}\right)$, $\mathrm{SrMn}\left(\mathrm{VO}_{4}\right) \mathrm{H}\left(\mathrm{J}=-10 \mathrm{~K}, \mathrm{Mn}-\mathrm{O}-\mathrm{Mn}=96.7^{\circ}\right)$ or $\mathrm{FeSeO}_{3} \mathrm{~F}$ with alternating chains $(\mathrm{J}=-5 \mathrm{~K} /$ - $2 \mathrm{~K}, \mathrm{Fe}-\mathrm{O}-\mathrm{F}$ and $\left.\mathrm{Fe}-\mathrm{F}-\mathrm{Fe} \sim 104^{\circ}\right) .{ }^{30-32}$ The corner-sharing situation with enhanced magnetic mediation by $\sigma$ overlap is reminiscent of transition metal halides, such as $\beta-\mathrm{FeF}_{3} \cdot \mathrm{H}_{2} \mathrm{O}$ $\left(\mathrm{Fe}-\mathrm{O} / \mathrm{F}-\mathrm{Fe}=180^{\circ}\right)$ showing a maximum around $120 \mathrm{~K}$ in $\chi(\mathrm{T})$ and $\mathrm{CsMnCl}_{3} \cdot 2 \mathrm{H}_{2} \mathrm{O}$ $\left(\mathrm{Mn}-\mathrm{Cl}-\mathrm{Mn}=126^{\circ}, \mathrm{J}=-6 \mathrm{~K}\right)$ with electronegative halides hampering the magnetic connectivity. ${ }^{33-35}$ 


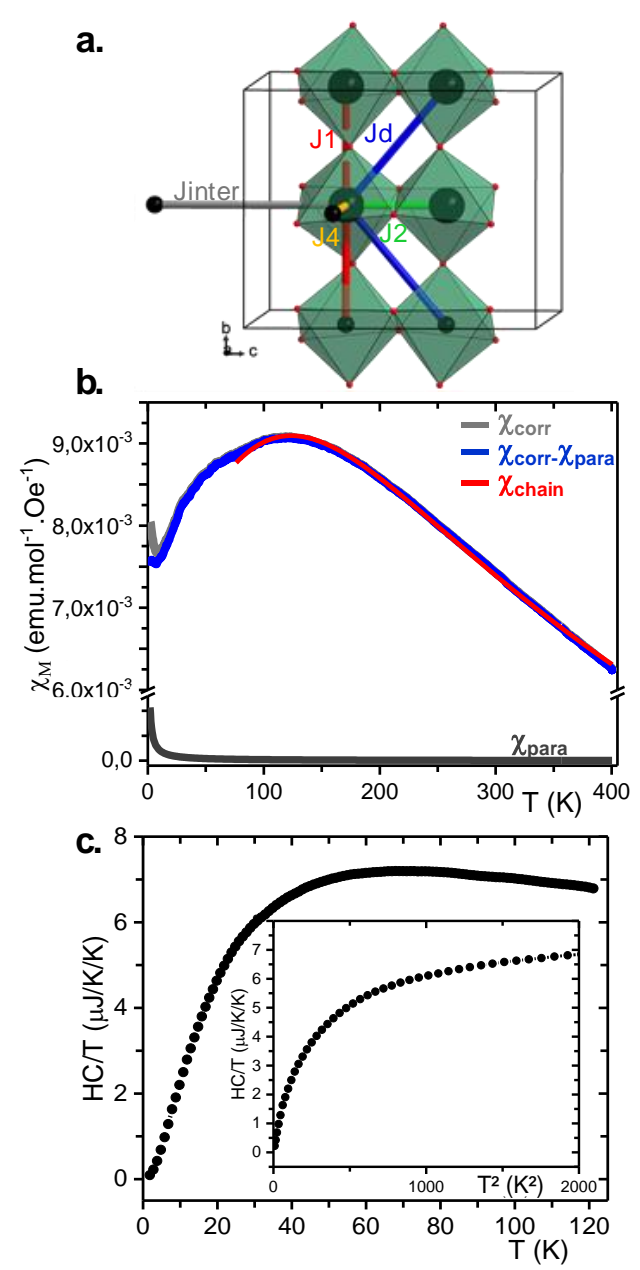

Figure 3. $\mathrm{BaFe}_{2}\left(\mathrm{As}_{2} \mathrm{O}_{5}\right)\left(\mathrm{AsO}_{3} \mathrm{OH}\right):$ a) Main identified magnetic exchange, b) experimental and fitted $\chi(\mathrm{T})$ plots c) $C p / T(T)$ and $C p / T\left(T^{2}\right)$ in the insert.

3) layers of $\mathrm{Fe}^{3+}$ square pyramidal dimers / pyro-arsenite in $\mathrm{Ba}_{2} \mathrm{Fe}_{2} \mathrm{O}\left(\mathrm{As}_{2} \mathrm{O}_{5}\right)_{2}$

$\mathrm{Ba}_{2} \mathrm{Fe}_{2} \mathrm{O}\left(\mathrm{As}_{2} \mathrm{O}_{5}\right)_{2}$ (compound (3)) crystallizes in the tetragonal $I 4 / \mathrm{mcm}$ (140) space group, with unit cell parameters $a=8,6665(4) \AA, c=16,107(2) \AA\left(\mathrm{R}_{\mathrm{obs}}=1.34 \%\right.$, $\left.\mathrm{wR}_{\mathrm{obs}}=1.79 \%\right)$. Details regarding collection and refinement parameters are given in Table 2 . The coordinates, thermal displacements and selected bond distances are shown in Tables $\mathrm{S} 2(\mathrm{~g}, \mathrm{~h}, \mathrm{i})$. The crystal structure is built of $\mathrm{FeO}_{5}$ square pyramid (SP) connected into $\mathrm{Fe}^{3+}{ }_{2} \mathrm{O}_{9}$ dimers through shared $\mathrm{O} 3$ apical apex, with Fe-Fe distances of 3.5551(8) $\AA$, see Fig. 1g. In the dimers the two basal planes are eclipsed by $45^{\circ}$, see Fig. $1 \mathrm{~h}$. In the $a b$ planes the dimers are separated by pyro-arsenite, each of them connecting 4 dimers by its four "free" corners and leading to thick double layers, separated by $\mathrm{Ba}^{2+}$ ions, see Fig.1i. The $\mathrm{As}^{3+}$ lone pairs point to the interlayer vacant space, see again Fig. S2m. We note that contrarily to the well-known layered oxychalcogenides with double perovskite blocks such as $\mathrm{Sr}_{3} \mathrm{Fe}_{2} \mathrm{O}_{5} \mathrm{Cu}_{2} \mathrm{Ch}_{2}(\mathrm{Ch}=\mathrm{S}, \mathrm{Se})$ in which the $\mathrm{FeO}_{5} \mathrm{SPs}$ are completed by a long $\mathrm{Fe}-\mathrm{Ch}$ bond across the alkali earth layers, ${ }^{36,37}$ here we deal with true penta coordinated ferric ions arranged in dimers, similar to the dimeric units within the perovskite slabs of $\mathrm{YBaCuFeO}_{5}$, but isolated and not eclipsed. ${ }^{38}$ It is remarkable that such units maximize the Fe-O-Fe orbital overlap mediated by two equally short $\mathrm{Fe}-\mathrm{O}$ bonds of $1.7756 \AA$ and $\mathrm{Fe}-\mathrm{O}-\mathrm{Fe}$ angle of $180^{\circ}$, much shorter than in $\mathrm{YBaCuFeO}_{5}$ (with $\mathrm{Fe}^{3+}-\mathrm{O}_{\text {apical }}=1.9389 \AA$ ) or $\mathrm{Sr}_{4} \mathrm{Fe}_{2} \mathrm{O}_{6} \mathrm{CO}_{3}$ (with $\mathrm{Fe}^{3+}-\mathrm{O}_{\text {apical }}$ distances of $1.9042 \AA$ ). ${ }^{38,39}$ Here the coordination of the common oxygen is achieved by the two $\mathrm{Fe}^{3+}$ only, leaving BVS of 2.30 for this ligand. This distance is particularly short, even compared to standard $\mathrm{FeO}_{4}$ polyhedra 
$\left(\sim 2.0\right.$ in magnetite or hexagonal ferrite). ${ }^{40-42}$ To the best of our knowledge, the shortest reported Fe-O distance was reported for $\alpha-\mathrm{BaFe}^{2+}{ }_{2} \mathrm{P}_{2} \mathrm{O}_{8}\left(\mathrm{Fe}^{2+}-\mathrm{O}=1.784(1) \AA\right)$ but concerns $\mathrm{Fe}^{2+}$ in strongly distorted trigonal-bipyramidal coordination, leaving compound (3) with an even shortest Fe-O distance. ${ }^{43}$ The refined $\mathrm{Ba}_{2} \mathrm{Fe}_{2} \mathrm{O}\left(\mathrm{As}_{2} \mathrm{O}_{5}\right)_{2}$ formula is in good agreement with the EDS analysis performed, leading to $\mathrm{Ba} / \mathrm{Fe} / \mathrm{As}$ in 1.98/1.98/4.04 averaged ratio, see Fig. S3 (middle plot) for details.

Magnetic exchange paths and DFT calculations : For $\mathrm{Ba}_{2} \mathrm{Fe}_{2} \mathrm{O}\left(\mathrm{As}_{2} \mathrm{O}_{5}\right)_{2}$ we identified two main exchanges: $\mathrm{J}_{\mathrm{dim}}$ is a SE AFM path expected very strong for reasons given above, and then between them, in the layers $\mathrm{J}_{2}$ is mediated by SSE paths with ideal $0^{\circ}$ dihedral $\angle \mathrm{Fe}-\mathrm{O}-\mathrm{O}-\mathrm{Fe}$ angles but strong hybridization of oxygen $\mathrm{p}$ levels in $\mathrm{As}^{3+}-\mathrm{O}$ bonds. Finally, between the layers the shortest $\mathrm{O}$... O contacts are $3.33 \AA$ long, well above the sum of van der Waals ionic radii, but an extra interlayer $\mathbf{J}_{3}$ was calculated for confirmation, see Fig. 4a. For our GGA+U calculations, dealing with SBP Fe ${ }^{3+}$ species we chose the on-site Coulomb repulsion energy $\mathrm{U}=7 \mathrm{eV}$, which is an intermediate value between $\mathrm{U}=6 \mathrm{eV}$, ideal for $\mathrm{FeO}_{6}$ and $\mathrm{U}=8 \mathrm{eV}$ ideal for $\mathrm{FeO}_{4},{ }^{44}$ returning $\mathrm{J}_{\mathrm{dim}}=+259.03 \mathrm{~K}(\mathrm{AFM}), \mathrm{J}_{2}=-3.33 \mathrm{~K}(\mathrm{FM})$, and $\mathrm{J}_{3}=+1.28 \mathrm{~K}(\mathrm{AFM})$. Details related to selected magnetic configurations, corresponding relative energies calculated and geometrical informations related to magnetic exchange paths can be found in Tables and Fig. S4(f,g,h). Of course, the linear Fe-O-Fe path within nearly isolated dimers maximizes the exchanges, and the prominent example for such strong AFM exchange is the Cairo pentagonal lattice of $\mathrm{Bi}_{2} \mathrm{Fe}_{4} \mathrm{O}_{9}$, in which $\mathrm{Fe}^{3+} \mathrm{O}_{4}$ tetrahedra similarly sharing corners within a linear $\mathrm{Fe}-\mathrm{O}-\mathrm{Fe}$ bridge result in $\sim 278 \mathrm{~K}$ exchanges, from inelastic neutron scattering. ${ }^{45}$ Experimentally, the measurement of reliable $\chi(\mathrm{T})$ data turned out to be not trivial, due to a plethora of limiting parameters: i) only a small amount of tiny crystals (max dim. $<50 \mu \mathrm{m}$ ) have been identified by faces and hand isolated and cleaned in grease. Thus the total sample weight was not properly estimated. ii) The faces of most of the crystals were covered by magnetite-like compound, and show room-temperature ferromagnetism. iii) The intrinsic and the sample holder diamagnetism gave significant strong signal compared to the weak $\chi(\mathrm{T})$ range estimated from the calculated Js. Experimentally, $\mathrm{M}(\mathrm{H})$ curves at $300 \mathrm{~K}$ are negative below $\mathrm{H}=1.5 \mathrm{~T}$, see Fig. S5b (right), and results in $\chi_{\mathrm{DC}}(\mathrm{T})$ systematically dominated by extrinsic ferromagnetism. Our best alternative consists of using $\chi_{\mathrm{AC}}$ measurement under a bias field $\mathrm{H}_{\mathrm{DC}}$ of $2 \mathrm{~T}$ to supress the saturated FM contribution. $\chi(\mathrm{T})$ is shown in Fig. $4 \mathrm{~b}$ after correction of a diamagnetic contribution. It was fitted using the partition function method (see below), given below for $\mathrm{S}=5 / 2$ dimers $^{46}$;

$$
\left.\chi(T)=\frac{N_{A} \times g^{2} \times \mu_{B}^{2}}{k_{B} T} \frac{e^{x}+5 e^{3 x}+14 e^{6 x}+30 e^{10 x}+55 e^{15 x}}{1+3 e^{x}+5 e^{3 x}+7 e^{6 x}+9 e^{10 x}+11 e^{15 x}} \text { (Equation } 4\right)
$$

where $x=J / k_{\mathrm{B}} T$ and $N_{\mathrm{A}}, \mu_{\mathrm{B}}$, and $k_{\mathrm{B}}$ have their usual meanings. To take into account the interdimer interactions, we used as for compound (1) a mean Field-Weiss approximation (see equation 1) with $\mathrm{z}=6$ neighbouring ( 4 in plane and two apical ones) dimers around a central one. Here $J_{\text {inter }}$ corresponds to the average interaction, e.g. $J_{\text {inter DFT }}=1 / 6\left(4 \mathrm{~J}_{2}-2 \mathrm{~J}_{3}\right)=1.79 \mathrm{~K}$. Finally, the susceptibility was scaled refining the $\mathrm{g}^{2}$ term. Besides the high divergence of the experimental data, $\chi(T)$ appears rather well reproduced using our DFT values. Following the strong exchanges in the dimers the influence of $\mathrm{J}_{\text {inter }}$ is subtle, leading to a reasonable fit mainly dominated by the $\mathrm{J}_{\mathrm{dim}}$ effect, i.e. $\mathrm{J}_{\mathrm{dim}}=+255(4) \mathrm{K}$, $\mathrm{J}_{\text {inter }}=-18.6(1) \mathrm{K}$. On the Fig. $4 \mathrm{~b}$ we also plot the calculated data for $\mathrm{J}_{\mathrm{dim}}=-300 \mathrm{~K}$ and $-200 \mathrm{~K}$ and $\mathrm{J}_{\text {inter }}=1.79 \mathrm{~K}$ which allows roughly to 
validate the DFT calculations. Finally, the system corresponds to weakly coupled layers of robust AFM dimers. The calculated interlayer $\mathrm{J}_{3}$ of $+1.28 \mathrm{~K}$ do not allow to certify the existence of magnetic ordering at low temperature. Indeed, the precision of our $\mathrm{Cp}(\mathrm{T})$ measurement was also limited by the small amount of available sample, see Fig. 4c. In addition taking into account the giant exchanges within the dimers most of the magnetic entropy should survive at high temperature leading to a very weak $\lambda$ - type anomaly, if any. Our data shown in Fig. $4 \mathrm{c}$ are very noisy and a lot of pseudo-maxima coexist, including one at $8 \mathrm{~K}$. Indeed, this peak at $T>J_{3}$ is so far assigned to spurious data, which enhance a main 2D topology.

Molecular orbitals: From geometrical considerations, one could expect specific crystal field with enhanced orbital overlap occurring from the linear and short $\mathrm{Fe}-\mathrm{O}-\mathrm{Fe}$ units $(\mathrm{Fe}-\mathrm{O}=1.776(1) \AA)$. To gain insight into this specific feature, we carried out extended-Hückel tight-binding calculations for individual $\mathrm{FeO}_{5}, \mathrm{FeO}_{4}$ and connected $\mathrm{SP} \mathrm{Fe}_{2} \mathrm{O}_{9} .{ }^{47,48}$ Our results are summarized in Fig. 5 where the $\mathrm{Fe}^{3+}\left(d^{5}\right)$ ion in the high-spin state is assumed. Focusing on the apical interaction the apical Fe-O bond destabilizes the $d_{\mathrm{z} 2}$ orbital form found nearly at the same level than the $\mathrm{t} 2$ manifold in the square planar $\mathrm{FeO}_{4}$. In the dimeric unit the antibonding $d_{z 2}$ level is split in one $\sigma^{*} d_{\mathrm{z} 2}-\mathrm{O}_{\mathrm{s}}$ and one $\sigma^{*} d_{\mathrm{z} 2}-\mathrm{O}_{\mathrm{pz}}$ separated by $\sim 0.35 \mathrm{eV}$ with almost no oxygen $s p$ mixing due to the very high point 422 symmetry of $\mathrm{O} 3$ and the perfectly linear $\mathrm{Fe}-\mathrm{O} 3-\mathrm{Fe}$ bridge. All other $d$ levels are doubly degenerated in the dimer, as expected. However, the $d_{x z} / d_{y z}$ doublet of individual groups is split after merging into dimer. This split involve no interaction with the central oxygen in the lower state but a $\pi^{*}$ bond with the remaining $\mathrm{O} 3 p$ states $\left(p_{\mathrm{x}}, p_{\mathrm{y}}\right)$ for the higher state. Finally, the situation is very similar to those shown for dimers isolated from the double perovskite slabs $\mathrm{Sr}_{3} \mathrm{Fe}_{2} \mathrm{O}_{5} \mathrm{Cu}_{2} \mathrm{~S}_{2}{ }^{36}$ and we did not find any significant effect arising from the eclipsed geometry of the $\mathrm{Fe}_{2} \mathrm{O}_{9}$ dimers in compound (3). In the latter the most impressive change concerns the destabilization of the $d_{\mathrm{x} 2-\mathrm{y} 2}$ state which relatively lie $0.7 \mathrm{eV}$ higher than for compound (3) due to shorter equatorial Fe-O bonds 1.97 against $2.05 \AA$. 


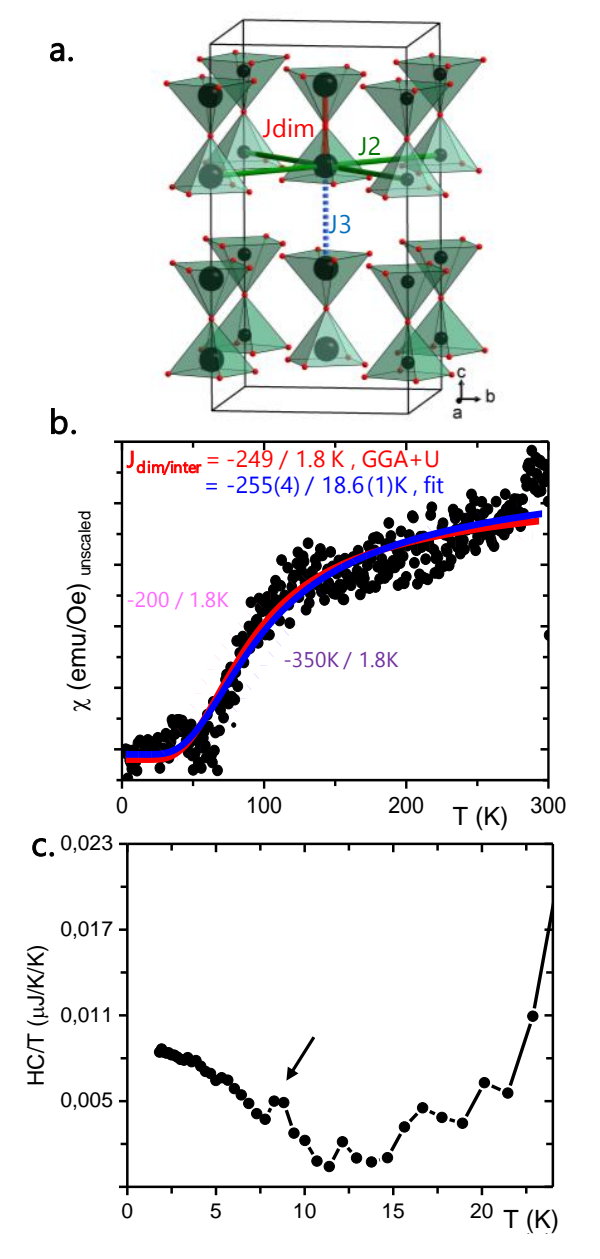

Figure 4. $\mathrm{Ba}_{2} \mathrm{Fe}_{2} \mathrm{O}\left(\mathrm{As}_{2} \mathrm{O}_{5}\right)_{2}:$ a) Main identified magnetic exchanges, $\left.b\right) \chi_{A C}(T)$ under $H_{D C}=2 T$ and the corresponding interacting dimer fits. c) $C p(T)$ plot.

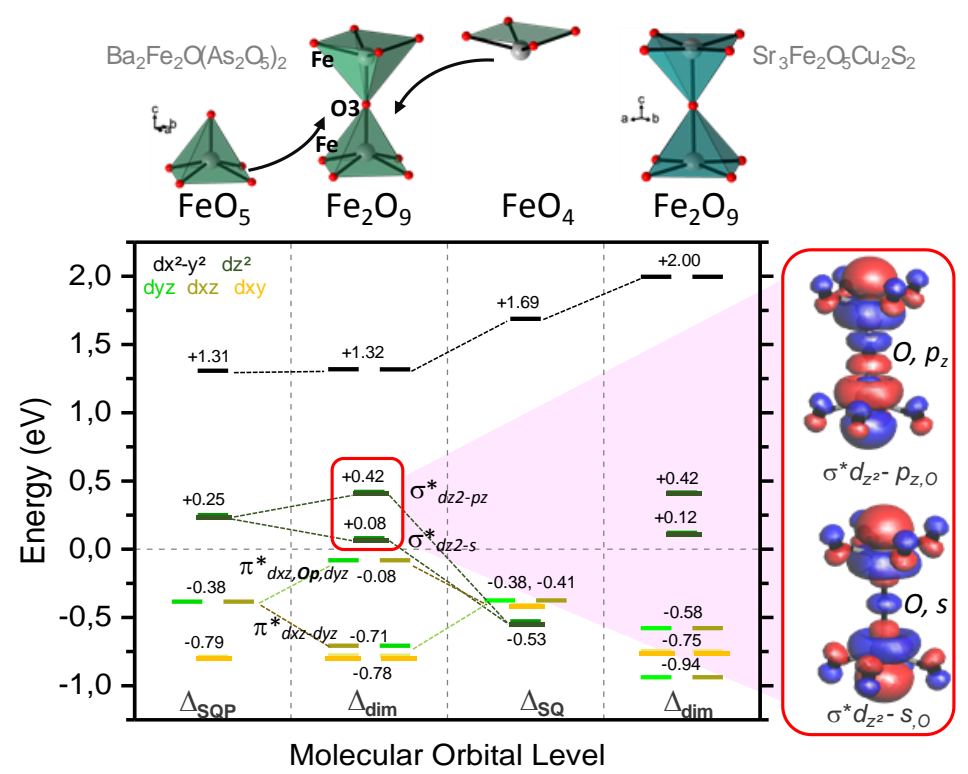

Figure 5. Representation of the molecular orbital levels calculated for $\mathrm{Ba}_{2} \mathrm{Fe}_{2} \mathrm{O}\left(\mathrm{As}_{2} \mathrm{O}_{5}\right)_{2}$ (with coalescence of $\mathrm{FeO}_{5}$ and $\mathrm{FeO}_{4}$ into a dimer) and for the dimers within $\mathrm{Sr}_{3} \mathrm{Fe}_{2} \mathrm{O}_{5} \mathrm{Cu}_{2} \mathrm{~S}_{2}$. 


\section{3D dense packing / ortho- and pyro-arsenite in $\mathrm{Fe}_{3}\left(\mathrm{As}_{2} \mathrm{O}_{5}\right)\left(\mathrm{AsO}_{3}\right) \mathrm{Cl}$ :}

Structural Analysis: The compound (4) was prepared in absence of $\mathrm{Ba}^{2+}$ counter ions, in order to increase the iron packing within a 3D edifice. The structure of $\mathrm{Fe}_{3}\left(\mathrm{As}_{2} \mathrm{O}_{5}\right)\left(\mathrm{AsO}_{3}\right) \mathrm{Cl}$ was solved from single-crystal XRD data at room temperature. It crystallizes in the triclinic $P-1$ (2) space group with $a=5.5346(12) \AA, b=8.5292(19) \AA, c=9.626(2) \AA, \alpha=72.401(12) \circ$, $\beta=89.596(13)^{\circ}, \quad \gamma=78.203(13)^{\circ}\left(\mathrm{R}_{\mathrm{obs}}=4.24 \%\right)$. The refined formula $\mathrm{Fe}_{3}\left(\mathrm{As}_{2} \mathrm{O}_{5}\right)\left(\mathrm{AsO}_{3}\right) \mathrm{Cl}$ is in great agreement with the one obtained from averaged EDS analysis of $\mathrm{Fe} / \mathrm{As} / \mathrm{Cl}$ in a 3.2 / 2.7 / 1.0 ratio, see Fig. S3c.

Refinement parameters can be found in Table 1, while details such as atomic positions, thermal displacements, selected distances and bond valences calculations can be found in Tables $\mathrm{S} 2(\mathrm{j}, \mathrm{k}, 1) . \mathrm{Fe}_{3}\left(\mathrm{As}_{2} \mathrm{O}_{5}\right)\left(\mathrm{AsO}_{3}\right) \mathrm{Cl}$ contains four independent iron positions assigned to specific valence from BVS and local magnetic moments DFT calculations, i.e. $\mathrm{Fe} 1^{3+}(\mathrm{BVS}=3.03(2))$, $\mathrm{Fe}^{2+}(\mathrm{BVS}=2.06(1)), \mathrm{Fe}^{3+}(\mathrm{BVS}=3.00(1)), \mathrm{Fe}^{2.5+}(\mathrm{BVS}=2.48(1))$, see Table S21. The crystal structure is based on $\left[\mathrm{Fe}_{4} \mathrm{Cl}_{2} \mathrm{O}_{12}\right]^{15-}$ tetramers sharing edges containing $\mathrm{Fe}^{3+} \mathrm{O}_{6}$ and $\mathrm{Fe}{ }^{2.5+} \mathrm{O}_{5} \mathrm{Cl}$ octahedra, see Fig. $1 \mathrm{j}$ leaving intra-lozenge Fe-Fe distances between 3.14 and $3.38 \AA$ A. These units concentrate the strongest magnetic exchanges and the stability of the mixed $\mathrm{Fe}^{2.5+}$ is promoted by direct $\mathrm{Fe}-\mathrm{Cl}$ bond, $\mathrm{Cl}$ being very electronegative. Similar behaviour is observed in the $\mathrm{Fe}^{2+} / \mathrm{Fe}^{3+}$ ordered $\left.\mathrm{BaFe}^{2.33+}{ }_{3}\left(\mathrm{Si}_{2} \mathrm{O}_{7}\right) \mathrm{O}(\mathrm{OH})_{0.77} \mathrm{Cl}_{0.23}\right)$ in which chloride solely coordinate $\mathrm{Fe}^{2+}$ site. ${ }^{49}$ Each lozenge like bloc are separated from each other from at least $4.65 \AA$ in the $a b$ plane. These units are interconnected by corner sharing with $\mathrm{Fe} 1{ }^{3+} \mathrm{O}_{6}$ (shortest $\mathrm{Fe}-\mathrm{Fe} 1$ distance $=3.571(1) \AA$ ) and $\mathrm{Fe}^{2+} \mathrm{O}_{4} \mathrm{Cl}_{2}$ octahedra. The large connectivity of the $\mathrm{Fe} 1$ and $\mathrm{Fe} 2$ bridges complicate the magnetic array, as discussed below. Finally, in the $a b$ plane, additional connections are carried out between the building blocks with apex sharing through ortho and pyro-arsenite $\mathrm{AsO}_{3} / \mathrm{As}_{2} \mathrm{O}_{5}$ groups, see Fig. $1(\mathrm{k}, 1)$. All of the lone pair related to the three arsenic sites are pointing toward the empty tunnels build from the Fe network, see again Fig. S2m. Here again, the divalent cations prefers heteroleptic $\mathrm{O} / \mathrm{Cl}$ coordination, creating a pseudo-3D edifice, see Fig. 1(k,1). The Fe2-Cl and Fe4-Cl distances of 2.646(2) and 2.441(2) $\AA$ respectively fall in the expected range, e.g. $\mathrm{d}\left(\mathrm{Fe}^{2+}-\mathrm{Cl}\right)=2.865(1), 2.490(4)$ and 2.739(4) $\AA$ in $\mathrm{Na}_{2} \mathrm{Fe}^{2+}{ }_{3}\left(\mathrm{P}_{2} \mathrm{O}_{7}\right)_{2}(\mathrm{CsCl}) .{ }^{50}$ On the opposite, most inorganic oxochlorides, $\mathrm{Cl}^{-}$tends to segregate with electropositive cations such as ammonium, alkali, alkali-earths to build porous or layered structure such as found in $\left(\mathrm{NH}_{4} \mathrm{Cl}\right) \mathrm{Fe}_{14}(\mathrm{OH})_{6}\left(\mathrm{PO}_{4}\right)_{6}\left(\mathrm{HPO}_{4}\right)_{2}, \mathrm{Ca}_{3} \mathrm{Fe}^{3+}{ }_{2} \mathrm{O}_{5} \mathrm{Cl}, \mathrm{Sr}_{2} \mathrm{Fe}^{3+} \mathrm{O}_{3} \mathrm{Cl}^{51-53}$ which differ from the mixed $\mathrm{Fe}(\mathrm{O}, \mathrm{Cl})_{6}$ coordination found in compound. Finally, one should mention that compound (4) is the second reported chloro-arsenite after $\mathrm{Pb}_{4} \mathrm{Fe}^{2+}\left(\mathrm{AsO}_{3}\right)_{2} \mathrm{Cl}_{4}\left(\mathrm{H}_{2} \mathrm{O}\right)_{2}$, with $\mathrm{Fe}-\mathrm{Cl}$ distance of $2.609(2) \AA .{ }^{17}$

\section{Spectroscopic characterization:}

UV-Visible spectra for $\mathrm{Fe}_{3}\left(\mathrm{As}_{2} \mathrm{O}_{5}\right)\left(\mathrm{AsO}_{3}\right) \mathrm{Cl}$ is given in Fig. 2 (black plot), and show a strong absorbance peak centred around $400 \mathrm{~nm}$ (blue-green absorption) in agreement with the orange-brown colour of the sample. The optical gap is around $2.5 \mathrm{eV}$. The infrared spectrum for $\mathrm{Fe}_{3}\left(\mathrm{As}_{2} \mathrm{O}_{5}\right)\left(\mathrm{AsO}_{3}\right) \mathrm{Cl}$ is discussed and shown in Fig. S2n.

Magnetic Properties: Eleven plausibly significant magnetic exchanges have been identified which requests time consuming DFT calculations and important computational resources for $\mathrm{Fe}_{3}\left(\mathrm{As}_{2} \mathrm{O}_{5}\right)\left(\mathrm{AsO}_{3}\right) \mathrm{Cl}$, therefore only simple configurations have been tested for preliminary conclusions, see Fig. and Table $\mathrm{S} 4(\mathrm{i}, \mathrm{j}, \mathrm{k})$. We found evidence of small amount of $\gamma$ - $\mathrm{Fe}_{2} \mathrm{O}_{3}$ in the 
sample (less than $1 \%$, see Fig. S5a), such that the magnetic susceptibility of $\mathrm{Fe}_{3}\left(\mathrm{As}_{2} \mathrm{O}_{5}\right)\left(\mathrm{AsO}_{3}\right) \mathrm{Cl}$ was measured at $\mathrm{H}=0.1 \mathrm{~T}$ after a preliminary alignment at room temperature of the magnetic maghemite domains. Such second phase, even in minor amount is also responsible for a weak ferromagnetic contribution already at room temperature evidenced on the $\mathrm{M}(\mathrm{H})$ plots, see Fig. S5b. The compound is 3D and orders antiferromagnetically below $\mathrm{T}_{\mathrm{N}}=97 \mathrm{~K}$ as shown by the sharp $\chi(\mathrm{T})$ peak. Above $\mathrm{T}_{\mathrm{N}}$, between 400 and $125 \mathrm{~K}$, a Curie Weiss law was fitted taking into account a temperature independent paramagnetic contribution $\chi_{0}$, giving $\theta_{\mathrm{CW}}=-24.53 \mathrm{~K}$ (denoting major AFM contributions inside the structure) and $\mu_{\text {eff }}=4.92 \mu_{\mathrm{B}} / \mathrm{Fe}$ lower than the $5.59 \mu_{\mathrm{B}} / \mathrm{Fe}$ value expected for $\mathrm{Fe}^{2.66+}$, assigned to the incertitude brought by the $\chi_{0}$ fit. $\mathrm{T}_{\mathrm{N}}$ was also evidenced by a weak $\lambda$-type anomaly on $\mathrm{C}_{\mathrm{P}}$, pronounced on $\mathrm{C}_{\mathrm{p}} / \mathrm{T}(\mathrm{T})$, see Fig. 6d. Besides the possible charge ordering on the Fe4 site assigned to a mixed $\mathrm{Fe}^{2.5+}$ valence, the connectivities of the trivalent $\mathrm{Fe} 1$ and divalent $\mathrm{Fe} 2$ sites are expected to bring significant degrees of frustration, being connected to four and six $\left[\mathrm{Fe}_{4} \mathrm{Cl}_{2} \mathrm{O}_{12}\right]^{15-}$ tetramers respectively. This topology might avoid the ordering of significant magnetic moments on this site and eventually an idle spin situation. On the opposite the calculated frustration index $-\theta_{\mathrm{CW}} / \mathrm{T}_{\mathrm{N}} \sim 0.25$, does not sign efficient frustration in agreement with the plausible ordering independently of Fe1,2. In absence of neutron powder data and magnetic structure features, we assume the sharp $\mathrm{M}(\mathrm{H})$ upturn above $\mu_{0} \mathrm{H}=2.5 \mathrm{~T}$ at $80 \mathrm{~K}$ ) to the $\mathrm{Fe} 1 / \mathrm{Fe} 2$ spin alignment under field. The critical field of this metamagnetic transition drastically lowers upon cooling ( $\mu_{0} . \mathrm{H}_{\mathrm{c}} \sim 1.3 \mathrm{~T}$ at $2 \mathrm{~K}$ with opening of field induced hysteresis loop). At this temperature an extra charge ordering behaviour should be taken into account.

Charge ordering: Below $\mathrm{T}=70 \mathrm{~K}, \chi(\mathrm{T})$ shows an upturn followed by a round maximum at $\sim 30 \mathrm{~K}$. In this region the $\mathrm{ZFC} / \mathrm{FC}$ divergence pictures the setting of a net moment, assorted with a $7.10^{-3} \mu_{\mathrm{B}} / \mathrm{F}$.U. remnant moment after correction of the maghemite contribution. While such broad phenomena might suggest $\mathrm{Fe}(4)^{2.5+} \rightarrow \mathrm{Fe}^{3+}, \mathrm{Fe}^{2+}$ charge ordering $(\mathrm{CO})$ occurring on the $\mathrm{Fe} 4$ site within the tetramers, and the local setting of ferromagnetic $\mathrm{Fe}(4)^{2+}-\mathrm{Cl}-\mathrm{Fe}(2)^{2+}$ ferromagnetic exchange based on Kanamori-Goodenough rules $\left(\mathrm{Fe}-\mathrm{Cl}-\mathrm{Fe}=115^{\circ}\right)$, it is also possible that uncompensated spins result from the complex charge distribution and $3 \mathrm{D}$ interplay of magnetic exchanges. At least, the smooth $\mathrm{Cp}(\mathrm{T})$ plot across this transition suggest a $2^{\text {nd }}$ order phenomena and the relatively weak $\chi(\mathrm{T})$ anomaly is reminiscent of $2^{\text {nd }}$ order $\mathrm{CO}$ such as observed in the $\eta-\mathrm{Na}_{1.286} \mathrm{~V}_{2} \mathrm{O}_{5}$ bronze ${ }^{54}$. A more direct evidence of $\mathrm{CO}$ was found after DFT calculations of several magnetic configurations in a simple cell (with two individual Fe4 positions), see Fig. S4k. The GGA+U (U=6 eV calculations of all models converge to a split of the Fe4 moments within the tetramers with $\mathrm{M}_{\mathrm{Fe} 4 \mathrm{a}}=4.3 \mu_{\mathrm{B}}$ and $\mathrm{M}_{\mathrm{Fe} 4 \mathrm{~b}}=3.7 \mu_{\mathrm{B}}$ consistent with $\mathrm{HS} \mathrm{Fe}{ }^{3+}\left(\mathrm{M}_{\text {expected }} \leq 5 \mu_{\mathrm{B}}\right)$ due to covalent effects) and $\mathrm{HS} \mathrm{Fe}{ }^{2+}\left(\mathrm{M}_{\text {expected }} \leq 4 \mu_{\mathrm{B}}\right.$ by covalent effects) respectively. Additionally, imposing two diagonal AFM exchanges inside the tetramers lead to a moment splitting for both $\mathrm{Fe} 3$ and $\mathrm{Fe} 4$ sites, which highlight the charge instability in these units, see Table $\mathrm{S} 41$ for details. $\mathrm{Fe}^{2.5+} \rightarrow \mathrm{Fe}^{2+}, \mathrm{Fe}^{3+}$ disproportionation is expected accompanied by a sensitive structural distortion. Further experiments including low-T XRD and PND are on the run to fix the question on this specific compound. 

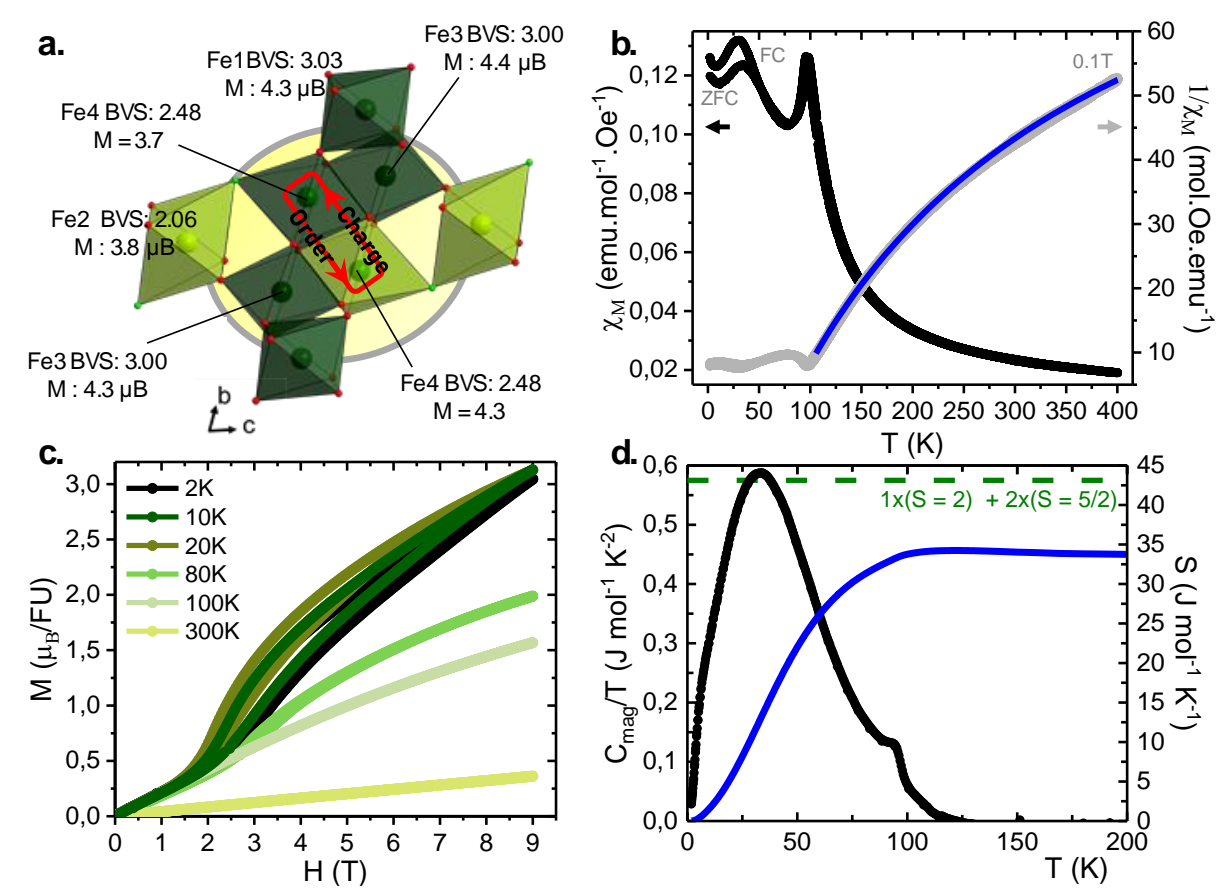

Figure 6. $\mathrm{Fe}_{3}\left(\mathrm{As}_{2} \mathrm{O}_{5}\right)\left(\mathrm{AsO}_{3}\right) \mathrm{Cl}:$ a) Low-temperature charge ordering (c.o.) at the Fe4 site b) experimental magnetic $\chi(T)$ and $1 / \chi(T)$ plots and fit (blue). c) $M(H)$ with evidence of metamagntetism below $\left.T_{N} . d\right) C m a g n / T(T)$ plot (black) and the recovered magnetic entropy (blue).

\section{CONCLUDING REMARKS}

We prepared four original inorganic iron arsenites, with $\mathrm{Fe}^{2+}, \mathrm{Fe}^{3+}$ or mixed iron valence states. They complete the dozen of reported compounds of these chemical series and highlight the versatile condensation of $\mathrm{AsO}_{3}$ units in dimers, chains or crowns, leading to efficient magnetic spacers, especially while associated with large cations such as $\mathrm{Ba}^{2+}$. The preparation of such compounds is difficult due to the redox and reactivity of the arsenite using high temperature solid routes. Here only solvothermal routes in narrow potential-pH windows may crystallize the solid products. This synthetic limitation and parasitic redox reactions following solid state routes could be pictured for instance, dealing with our attempts to prepare the compound (3) of formula $\mathrm{Ba}_{2} \mathrm{Fe}_{2} \mathrm{O}\left(\mathrm{As}_{2} \mathrm{O}_{5}\right)_{2}$ from $\mathrm{BaO}, \mathrm{Fe}_{2} \mathrm{O}_{3}$ and $\mathrm{As}_{2} \mathrm{O}_{3}$ leading to magnetite and As metal (then involving the $\mathrm{Fe}^{2+} \rightarrow \mathrm{Fe}^{3+}$ oxidation and concomitant $\mathrm{As}^{3+} \rightarrow \mathrm{As}^{0}$ reduction). Then we emphasize that hydrothermal or mineralogical conditions give the key-routes for rational synthesis in this system. Concerning the panel of magnetic chemical, crystalline and magnetic specificities demonstrated here, we found among others, a layered-VDW in compound (1), a rare example of $\mathrm{S}=5 / 2$ ladder in compound (2), the shortest $\mathrm{Fe}-\mathrm{O}-\mathrm{Fe}$ distances assorted with strong AFM exchanges within dimers in compound (3), and metamagnetism and charge ordering in compound (4). No doubt that these results should mark out the prospection for original low-D magnets in various arsenite-based chemical systems, and that the proposed synthetic conditions show simple routes to follow in this aim.

\section{ACKNOWLEDGMENT}

This work was carried out under the framework of the LOVE-ME project supported by the ANR (Grant ANR ANR-16-CE08-0023). The Fonds Européen de Développement Régional 
(FEDER), CNRS, Région Hauts-de-France and Ministère de l'Education Nationale, de l'Enseignement Supérieur et de la Recherche are acknowledged for funding the X-ray diffractometers. Chevreul Institute (FR 2638), Ministère de l'Education Nationale, de l'Enseignement Supérieur et de la Recherche, Région Hauts-de-France, FEDER are acknowledged for supporting this work. We thank Laurence Burylo, Nora Djelal \& Claire Minaud at the UCCS for the help with the measurements.

\section{ASSOCIATED CONTENT}

Supporting Information. The supporting information (one PDF file) is available free of charge on the website, at DOI :....

This file contain more detailed crystallographic information for the 4 compounds (such as atomic positions, equivalent thermal displacement, pertinent selected distances, bond valences sum calculations, and representation of the $\mathrm{As}^{3+}$ lone pair obtained from ELF calculations), results for the EDS microscopy analysis, details for DFT calculations (such as relative energies calculated, representation of the ordered spin states configurations employed, values of the geometrical parameters, and values of the magnetic exchange path coupling for different $U_{\text {eff }}$ values), and finally magnetic characterization details (such as evidence of $\gamma-\mathrm{Fe}_{2} \mathrm{O}_{3}$ in the compound (4) sample, or magnetization $\mathrm{M}(\mathrm{H})$ plot for each compounds).

On the website, you can also find the four structure of the compounds (as four .CIF files), and the corresponding checkcif (four PDF Files) related to their submission on the CCDC website.

These files are tagged as follow :

- $\mathrm{Ba} 2 \mathrm{Fe}\left(\mathrm{As}_{3} \mathrm{O}_{6}\right)_{2} \cdot \mathrm{H}_{2} \mathrm{O}: \mathrm{CSD} 2016600$

- $\mathrm{BaFe}_{2} \mathrm{As}_{2} \mathrm{O}_{5} \mathrm{AsO}_{3} \mathrm{OH}: \mathrm{CSD} 2016608$.

$-\mathrm{Ba}_{2} \mathrm{Fe}_{2} \mathrm{O}\left(\mathrm{As}_{2} \mathrm{O}_{5}\right)_{2}: \mathrm{CSD} 2016602$.

- $\mathrm{Fe}_{3}\left(\mathrm{As}_{2} \mathrm{O}_{5}\right)\left(\mathrm{AsO}_{3}\right) \mathrm{Cl}: \mathrm{CSD} 2016601$.

\section{AUTHOR INFORMATION}

Corresponding Author.

*olivier.mentre@univ-lille.fr

\section{ORCID}

Bastien Leclercq : 0000-0002-3165-322237

Angel M. Arevalo-Lopez: 0000-0002-8745-4990

Houria Kabbour : 0000-0002-9081-3261

Sylvie Daviero-Minaud: 0000-0003-3887-5585

Claire Minaud: -

Rénald David : -

Olivier Mentré : 0000-0002-1822-6003

\section{Notes}

The authors declare no competing financial interest. 


\section{References}

1 S. Lösel and $\mathrm{H}$. Hillebrecht, $\mathrm{Co}_{2} \mathrm{As}_{2} \mathrm{O}_{5}$ - The first cobalt(II)- arsenate(III), Zeitschrift fur Anorg. und Allg. Chemie, 2008, 634, 2299-2302.

2 R. Castañeda, E. Chavira and O. Peralta, Product prediction: Intermediates formed during rare earth reactions, J. Mex. Chem. Soc., 2014, 58, 82-87.

3 M. Radivojević, Inventing metallurgy in western Eurasia: A look through the microscope lens, Cambridge Archaeol. J., 2015, 25, 321-338.

4 O. Mentre, I. Blazquez-Alcover, S. Garcia-Martin, M. Duttine, A. Wattiaux, P. Simon, M. Huve and S. Daviero-Minaud, Mixed-Valence Iron Dumortierite $\mathrm{Fe}_{13.5}{ }^{2.22+}\left(\mathrm{As}^{5+} \mathrm{O}_{4-}\right.$ $\left.{ }_{x}\right)_{8}(\mathrm{OH})_{6}$ and Its Intricate Topotactic Exsolution at Mild Temperatures, Inorg. Chem., 2018, 57, 15093-15104.

5 I. Blazquez Alcover, S. Daviero-Minaud, R. David, D. Filimonov, M. Huvé, J. P. Attfield, H. Kabbour and O. Mentré, Selective Metal Exsolution in $\mathrm{BaFe}_{2-\mathrm{y}} \mathrm{M}_{\mathrm{y}}\left(\mathrm{PO}_{4}\right)_{2}(\mathrm{M}$ $=\mathrm{Co}^{2+}, \mathrm{Ni}^{2+}$ ) Solid Solutions, Inorg. Chem., 2015, 54, 8733-8743.

6 F. d'Yvoire and N. H. Dung, Structure cristalline du tris(arsénato)arsénite de fer(III), $\mathrm{Fe}_{2}\left[\mathrm{As}^{\mathrm{III}}\left(\mathrm{AsVO}_{4}\right)_{3}\right]$. Mise en évidence d'un désordre partiel des atomes d'arsenic(III) avec ordre linéaire, Acta Crystallogr. Sect. B Struct. Crystallogr. Cryst. Chem., 1979, 35, $1751-1755$.

7 F. C. Hawthorne, Schneiderhoehnite, $\mathrm{Fe}^{2+} \mathrm{Fe}^{3+} \mathrm{Ass}_{5}^{3+} \mathrm{O}_{13}$, a densely packed arsenite structure, Can. Mineral., 1985, 23, 675-679.

8 G. Morin, G. Rousse and E. Elkaim, Crystal structure of tooeleite, $\mathrm{Fe}_{6}\left(\mathrm{AsO}_{3}\right)_{4} \mathrm{SO}_{4}(\mathrm{OH}) \cdot 4 \mathrm{H}_{2} \mathrm{O}$, a new iron arsenite oxyhydroxysulfate mineral relevant to acid mine drainage, Am. Mineral., 2007, 92, 193-197.

$9 \quad \mathrm{H}$. Sarp and L. Guenee, Radovanite, $\mathrm{Cu}_{2} \mathrm{Fe}^{3+}\left(\mathrm{As}^{5+} \mathrm{O}_{4}\right)\left(\mathrm{As}^{3+} \mathrm{O}_{2} \mathrm{OH}\right) 2 \mathrm{H}_{2} \mathrm{O}$, a new mineral: its description and crystal structure, Arch. des Sci. compte rendu des séances la Soc., 2002, 55, 47-55.

10 M. Binnewies, M. Schmidt and P. Schmidt, Chemical Vapor Transport Reactions Arguments for Choosing a Suitable Transport Agent, Zeitschrift fur Anorg. und Allg. Chemie, 2017, 643, 1295-1311.

11 M. Weil, $\mathrm{Fe}_{3}{ }^{\mathrm{II}} \mathrm{Fe}_{4}{ }^{\mathrm{III}}\left(\mathrm{AsO}_{4}\right)_{6}$, the first arsenate adopting the $\mathrm{Fe}_{7}\left(\mathrm{PO}_{4}\right)_{6}$ structure type, Acta Crystallogr. Sect. E Struct. Reports Online, 2004, 60, 139-141.

12 V. M. Kovrugin, E. E. Gordon, E. E. Kasapbasi, M. H. Whangbo, M. Colmont, O. I. Siidra, S. Colis, S. V. Krivovichev and O. Mentré, Bonding scheme, hydride character, and magnetic paths of $\left(\mathrm{HPO}_{3}\right)^{2-}$ Versus $\left(\mathrm{SeO}_{3}\right)^{2-}$ building units in solids, J. Phys. Chem. $C, 2016,120,1650-1656$.

13 R. David, H. Kabbour, S. Colis and O. Mentré, Slow Spin Dynamics between Ferromagnetic Chains in a Pure-Inorganic Framework, Inorg. Chem., 2013, 52, 1374213750.

14 R. David, A. Pautrat, D. Filimonov, H. Kabbour, H. Vezin, M.-H. Whangbo and O. Mentré, Across the Structural Re-Entrant Transition in $\mathrm{BaFe}_{2}\left(\mathrm{PO}_{4}\right)_{2}$ : Influence of the Two-Dimensional Ferromagnetism, J. Am. Chem. Soc., 2013, 135, 13023-13029. 
15 H. Kabbour, R. David, A. Pautrat, H. Koo, M. Whangbo, G. André and O. Mentré, A Genuine Two-Dimensional Ising Ferromagnet with Magnetically Driven Re-entrant Transition, Angew. Chemie Int. Ed., 2012, 51, 11745-11749.

16 R. David, H. Kabbour, A. Pautrat, N. Touati, M. H. Whangbo and O. Mentré, Twoorbital three-electron stabilizing interaction for direct $\mathrm{Co}^{2+} \mathrm{As}^{3+}$ bonds involving squareplanar $\mathrm{CoO}_{4}$ in $\mathrm{BaCoAs}_{2} \mathrm{O}_{5}$, Angew. Chemie - Int. Ed., 2014, 53, 3111-3114.

17 F. Pertlik and G. Schnorrer, A re-appraisal of the chemical formula of nealite, $\mathrm{Pb}_{4} \mathrm{Fe}\left(\mathrm{AsO}_{3}\right)_{2} \mathrm{Cl}_{4} \cdot 2 \mathrm{H}_{2} \mathrm{O}$, on the basis of a crystal structure determination, Mineral. Petrol., 1993, 48, 193-200.

18 T. Araki and P. B. Moore, Dixenite, $\mathrm{Cu}^{1+} \mathrm{Mn}^{2+}{ }_{14} \mathrm{Fe}^{3+}(\mathrm{OH})_{6}\left(\mathrm{As}^{3+} \mathrm{O}_{3}\right)_{5}\left(\mathrm{Si}^{4+} \mathrm{O}_{4}\right)_{2}\left(\mathrm{As}^{5+} \mathrm{O}_{4}\right)$ : metallic $\left[\mathrm{As}^{3+}{ }_{4} \mathrm{Cu}^{1+}\right]$ clusters in an oxide matrix, Am. Mineral., 1981, 66, 1263-1273.

19 A. Coda, A. Dal Negro, C. Sabelli and V. Tazzoli, The crystal structure of stenhuggarite, Acta Crystallogr. Sect. B Struct. Crystallogr. Cryst. Chem., 1977, 33, 1807-1811.

20 M. A. Cooper and F. C. Hawthorne, Refinement of the crystal structure of schneiderhöhnite, Can. Mineral., 2016, 54, 707-713.

21 F. C. Cooper, Mark A and Hawthorne, The crystal structure of ludlockite, $\mathrm{PbFe}$ ${ }^{3+}{ }_{4} \mathrm{As}^{3+}{ }_{10} \mathrm{O}_{22}$, the mineral with pentameric arsenite groups and orange hair, Can. Mineral., 1996, 34, 79-89.

22 S. Graeser, H. Schwander, F. Demartin, C. M. Gramaccioli, T. Pilati and E. Reusser, Fetiasite $\left(\mathrm{Fe}^{2+}, \mathrm{Fe}^{3+}, \mathrm{Ti}_{3} \mathrm{O}_{2}\left[\mathrm{As}_{2} \mathrm{O}_{5}\right]\right.$, a new arsenite mineral: its description and structure determination, Am. Mineral., 1994, 79, 996-1002.

23 P. Keller, Ekatite, $\left(\mathrm{Fe}^{3+}, \mathrm{Fe}^{2}+, \mathrm{Zn}\right)_{12}(\mathrm{OH})_{6}\left[\mathrm{AsO}_{3}\right]_{6}\left[\mathrm{AsO}_{3}, \mathrm{HOSiO}_{3}\right]_{2}$, a new mineral from Tsumeb, Namibia, and its crystal structure, Eur. J. Mineral., 2001, 13, 769-777.

24 J. F. G.Kresse, Inst. für Mater. Vienna, 2012.

25 P. E. Blöchl, Projector augmented-wave method, Phys. Rev. B, 1994, 50, 17953-17979.

26 F. Pertlik, Die Kristallstruktur von $\mathrm{Cu}_{2} \mathrm{As}_{3} \mathrm{O}_{6} \mathrm{CH}_{3} \mathrm{COO}$, Zeitschrift für Krist., 1977, 145, 35-45.

27 M. Colmont, K. Lemoine, P. Roussel, H. Kabbour, J. Olchowka, N. Henry, H. Hagemann and O. Mentré, Identification and optical features of the $\mathrm{Pb}_{4} \mathrm{Ln}_{2} \mathrm{O}_{7}$ series $(\mathrm{Ln}=\mathrm{La}, \mathrm{Gd}$, Sm, Nd); genuine 2D-van der Waals oxides, Chem. Commun., 2019, 55, 2944-2947.

28 H. Benner and J. Wiese, Half-field EPR transitions in the 1D Heisenberg paramagnet TMMC, Phys. $B+C, 1979$, 96, 216-220.

29 H. Lu, T. Yamamoto, W. Yoshimune, N. Hayashi, Y. Kobayashi, Y. Ajiro and H. Kageyama, A Nearly Ideal One-Dimensional $S=5 / 2$ Antiferromagnet $\mathrm{FeF}_{3}$ (4,4'-bpy) $\left(4,4\right.$ '-bpy $=4,4^{\prime}$-bipyridyl) with Strong Intrachain Interactions, J. Am. Chem. Soc., 2015, 137, 9804-9807.

30 H. Ben Yahia, E. Gaudin, J. Darriet, M. Banks, R. K. Kremer, A. Villesuzanne and M. $\mathrm{H}$. Whangbo, Synthesis, crystal structure, magnetic properties, and electronic structure of the new ternary vanadate CuMnVO4, Inorg. Chem., 2005, 44, 3087-3093.

31 L. D. Sanjeewa, V. O. Garlea, M. A. McGuire, C. D. McMillen, H. Cao and J. W. Kolis, Structural and magnetic characterization of the one-dimensional $S=5 / 2$ 
antiferromagnetic chain system $\mathrm{SrMn}\left(\mathrm{V} \mathrm{O}_{4}\right)(\mathrm{OH})$, Phys. Rev. B, 2016, 93, 1-8.

32 S. Hu, M. Johnsson, J. M. Law, J. L. Bettis, M. H. Whangbo and R. K. Kremer, Crystal structure and magnetic properties of $\mathrm{FeSeO}_{3} \mathrm{~F}$ - Alternating antiferromagnetic $\mathrm{S}=5 / 2$ chains, Inorg. Chem., 2014, 53, 4250-4256.

33 G. Teufer, The crystal structure of $\beta$-iron(III) trifluoride trihydrate, $\beta-\mathrm{FeF}_{3} .3 \mathrm{H}_{2} \mathrm{O}$, Acta Crystallogr., 1964, 17, 1480-1480.

34 I. Dézsi, S. G. Sankar, L. N. Mulay, J. F. Houlihan and T. Pannaparayil, MAGNETIC ORDERING IN $\alpha$ - AND $\beta-F_{3} F_{3} .3 \mathrm{H}_{2} \mathrm{O}$, Le J. Phys. Colloq., 1988, 49, C8-1463-C8-1464.

35 T. Smith and S. A. Friedberg, Linear Chain Antiferromagnetism in $\mathrm{CsMnCl}_{3}, 2 \mathrm{H}_{2} \mathrm{O}$, Phys. Rev., 1968, 176, 660.

36 M. Lü, O. Mentré, E. E. Gordon, M. H. Whangbo, A. Wattiaux, M. Duttine, N. Tiercelin and $\mathrm{H}$. Kabbour, A comprehensive study of magnetic exchanges in the layered oxychalcogenides $\mathrm{Sr}_{3} \mathrm{Fe}_{2} \mathrm{O}_{5} \mathrm{Cu}_{2} \mathrm{Q}_{2}(\mathrm{Q}=\mathrm{S}, \mathrm{Se})$, J. Magn. Magn. Mater., 2017, 444, 147153.

37 S. J. Clarke, P. Adamson, S. J. C. Herkelrath, O. J. Rutt, D. R. Parker, M. J. Pitcher and C. F. Smura, Structures, physical properties, and chemistry of layered oxychalcogenides and oxypnictides, Inorg. Chem., 2008, 47, 8473-8486.

38 V. Caignaert, I. Mirebeau, F. Bourée, N. Nguyen, A. Ducouret, J. M. Greneche and B. Raveau, Crystal and magnetic structure of $\mathrm{YBaCuFeO}_{5}$, J. Solid State Chem., 1995, 114, 24-35.

39 K. Yamaura, Q. Huang, J. W. Lynn, R. W. Erwin and R. J. Cava, Synthesis, crystal structure, and magnetic order of the layered iron oxycarbonate $\mathrm{Sr}_{4} \mathrm{Fe}_{2} \mathrm{O}_{6} \mathrm{CO}_{3}$, J. Solid State Chem., 2000, 152, 374-380.

40 M. E. Fleet, The structure of magnetite, Acta Crystallogr. Sect. B Struct. Crystallogr. Cryst. Chem., 1981, 37, 917-920.

41 W. D. Townes, J. H. Fang and A. J. Perrotta, The crystal structure and refinement of ferrimagnetic barium ferrite, $\mathrm{BaFe}_{12} \mathrm{O}_{19}$, Zeitschrift fur Krist., 1967, 125, 437-449.

42 X. Obradors, A. Collomb, M. Pernet, D. Samaras and J. C. Joubert, X-ray analysis of the structural and dynamic properties of $\mathrm{BaFe}_{12} \mathrm{O}_{19}$ hexagonal ferrite at room temperature, J. Solid State Chem., 1985, 56, 171-181.

43 B. Leclercq, H. Kabbour, A. Arevalo-Lopez, M. Huvé, S. Daviero-Minaud, C. Minaud, I. Blazquez Alcover and O. Mentré, Polymorphs, phase transitions and stability in $\mathrm{BaM}_{2}\left(\mathrm{PO}_{4}\right)_{2} \mathrm{M}=\mathrm{Mn}, \mathrm{Fe}$, Co systems, Inorg. Chem. Front., 2019, 7, 239-246.

44 A. A. Tsirlin, I. Rousochatzakis, D. Filimonov, D. Batuk, M. Frontzek and A. M. Abakumov, Spin-reorientation transitions in the Cairo pentagonal magnet $\mathrm{Bi}_{4} \mathrm{Fe}_{5} \mathrm{O}_{13} \mathrm{~F}$, Phys. Rev. B, 2017, 96, 1-10.

45 K. Beauvois, V. Simonet, S. Petit, J. Robert, F. Bourdarot, M. Gospodinov, A. A. Mukhin, R. Ballou, V. Skumryev and E. Ressouche, Dimer Physics in the Frustrated Cairo Pentagonal Antiferromagnet $\mathrm{Bi}_{2} \mathrm{Fe}_{4} \mathrm{O}_{9}$, Phys. Rev. Lett., 2020, 124, 127202.

46 O. Kahn, Molecular Magnetism, 1993.

47 D. Dai, J. Ren, W. Liang and H. Whangbo, SAMOA (Structure and Molecular Orbital 
Analyzer).

48 R. Hoffmann, An Extended Hückel Theory. I. Hydrocarbons, J. Chem. Phys., 1963, 39, 1397-1412.

49 A. R. Kampf, A. C. Roberts, K. E. Venance, G. E. Dunning and R. E. Walstrom, FERROERICSSONITE, THE Fe2+ ANALOGUE OF ERICSSONITE, FROM EASTERN FRESNO COUNTY, CALIFORNIA, U.S.A., Can. Mineral., 2011, 49, 587594.

50 J. Gao, J. Li, D. Sulejmanovic and S. J. Hwu, $\mathrm{M}_{3}\left(\mathrm{P}_{2} \mathrm{O}_{7}\right)_{2}{ }^{2-}$-type open frameworks featuring $\left[\mathrm{M}_{2} \mathrm{O}_{8}\right]$ and $\left[\mathrm{M}_{3} \mathrm{O}_{12}\right]$ multinuclear transition-metal oxide units. Serendipitous synthesis of six polymorphic salt-inclusion magnetic solids: $\mathrm{Na}_{2} \mathrm{M}_{3}\left(\mathrm{P}_{2} \mathrm{O}_{7}\right)_{2} \cdot \mathrm{ACl}(\mathrm{M}=$ $\mathrm{Mn}, \mathrm{Fe} ; \mathrm{A}=\mathrm{Rb}, \mathrm{Cs})$ and $\mathrm{K}_{2} \mathrm{M}_{3}\left(\mathrm{P}_{2} \mathrm{O}_{7}\right)_{2} \cdot \mathrm{CsCl}(\mathrm{M}=\mathrm{Fe}, \mathrm{Mn})$, Inorg. Chem., 2015, 54, 1136-1144.

51 A. Guesdon, L. Adam and B. Raveau, A new iron (II) hydroxyphosphate containing linear ammonium chloride chains: $\left(\mathrm{NH}_{4} \mathrm{Cl}\right) \mathrm{Fe}_{14}(\mathrm{OH})_{6}\left(\mathrm{PO}_{4}\right) 6\left(\mathrm{HPO}_{4}\right)_{2}$, Solid State Sci., 2011, 13, 1584-1588.

52 J. F. Ackerman, The preparation and structures of the alkaline earth iron oxyhalides, $J$. Solid State Chem., 1991, 92, 496-513.

53 A. L. Hector, J. A. Hutchings, R. L. Needs, M. F. Thomas and M. T. Weller, Structural and Mössbauer study of $\mathrm{Sr} 2 \mathrm{FeO} 3 \mathrm{X}(\mathrm{X}=\mathrm{F}, \mathrm{Cl}, \mathrm{Br})$ and the magnetic structure of $\mathrm{Sr}_{2} \mathrm{FeO}_{3} \mathrm{~F}$, J. Mater. Chem., 2001, 11, 527-532.

54 F. Duc, P. Millet, S. Ravy, A. Thiollet, F. Chabre, A. M. Ghorayeb, F. Mila and A. Stepanov, Low-temperature superstructure and charge-ordering effect in $\mathrm{n}-\mathrm{Na}_{1.286} \mathrm{~V}_{2} \mathrm{O}_{5}$, Phys. Rev. B.

For Table of contents Only. 